\title{
Histidine deficiency has a negative effect on lactational performance of dairy cows
}

\author{
F. Giallongo, ${ }^{*}$ M. T. Harper, ${ }^{*}$ J. Oh, ${ }^{*}$ C. Parys, $†$ I. Shinzato, $\ddagger$ and A. N. Hristov* ${ }^{* 1}$ \\ *Department of Animal Science, The Pennsylvania State University, University Park 16802 \\ †Evonik Nutrition and Care GmbH, 63457 Hanau, Germany \\ ¥Ajinomoto Co. Inc., Tokyo, Japan 104
}

\section{ABSTRACT}

A 10-wk randomized complete block design experiment with 24 Holstein cows was conducted to investigate the long-term effects of feeding a His-deficient diet on lactational performance of dairy cows. Cows were blocked by days in milk, milk yield, and parity, and randomly assigned to 1 of the following 2 treatments: (1) His-adequate diet [HAD; providing $+166 \mathrm{~g} / \mathrm{d}$ over metabolizable protein (MP) requirements, according to the National Research Council (2001) and digestible His (dHis) supply of $68 \mathrm{~g} / \mathrm{d}$, or $2.5 \%$ of MP requirements] and (2) His-deficient diet (HDD; $+37 \mathrm{~g} / \mathrm{d}$ over MP requirements and dHis supply of $49 \mathrm{~g} / \mathrm{d}$, or $1.9 \%$ of MP requirements). Both HAD and HDD were supplemented with rumen-protected (RP) Met and Lys supplying digestible Met and digestible Lys at 2.4 and $2.4 \%$ and 7.2 and $7.1 \%$ of MP requirements, respectively. At the end of the 10-wk experiment, HDD was supplemented with RPHis (HDD+RPHis; total dHis supply of $61 \mathrm{~g} / \mathrm{d}$, or $2.4 \%$ of MP requirements) for an additional 9 d. Dry matter intake (DMI; 25.4 and 27.1 $\mathrm{kg} / \mathrm{d}$, standard error of the mean $=0.41$ ), yields of milk $(37.6$ and $40.5 \mathrm{~kg} / \mathrm{d}$, standard error of the mean $=$ 0.62 ), protein and lactose, energy-corrected milk, and milk and plasma urea- $\mathrm{N}$ were decreased by HDD compared with HAD. Feed and energy-corrected milk feed efficiencies, milk fat, protein and lactose concentrations, body weight, and body condition score of the cows were not affected by treatment. Apparent total-tract digestibility of dry and organic matter, crude protein, and neutral detergent fiber, and excretion of urinary $\mathrm{N}$ and urea-N were decreased by HDD compared with HAD. Concentration of plasma leptin tended to be decreased for HDD compared with HAD. Plasma concentrations of EAA (His, Leu, Lys, Val) and carnosine decreased and total EAA tended to be decreased in cows fed HDD compared with HAD. Muscle concentrations of free His, Leu, and Val decreased and Gly and $\beta$-alanine

Received September 12, 2016.

Accepted December 2, 2016.

${ }^{1}$ Corresponding author: anh13@psu.edu tended to be increased by HDD compared with HAD. Cows fed HDD had a lower blood hemoglobin concentration than cows fed HAD. At the end of the 10-wk study, the 9-d supplementation of HDD with RPHis (i.e., HDD+RPHis) increased DMI and plasma His, and tended to increase energy-corrected milk yield and plasma carnosine, compared with HDD. In conclusion, feeding a diet deficient in dHis supplying adequate MP, digestible Met, and digestible Lys affected negatively lactational performance of dairy cows. These results confirm our previous findings that low dietary His supply can impair DMI, yields of milk and milk protein, and blood hemoglobin in dairy cows.

Key words: histidine, dry matter intake, performance, dairy cow

\section{INTRODUCTION}

Meeting the AA requirements of lactating dairy cows is a complex task, particularly when feeding diets close to the MP requirements (NRC, 2001) of the cows. In such diets, the supply of EAA such as Met and Lys is more likely to be insufficient, causing potential losses in milk and milk protein production (Socha et al., 2005; Sinclair et al., 2014). Experiments conducted at The Pennsylvania State University (Lee et al., 2012; Giallongo et al., 2015, 2016) have shown that His is another limiting AA in lactating dairy cows fed MP-deficient diets based on corn silage and alfalfa haylage. Lapierre et al. (2008) and Lee et al. (2012) suggested that the requirement of digestible His (dHis) should be similar to that of digestible Met (dMet; i.e., 2.2\% of MP requirements; Schwab et al., 2005) based on the similar metabolism of His and Met across the splanchnic and mammary gland tissues and their concentration in milk protein. Lee et al. (2012) observed a decrease in plasma His concentrations and trends for lower DMI and milk yield in cows fed a MP-deficient diet (balanced for Lys and Met) providing dHis at $1.8 \%$ versus $2.3 \%$ of MP requirements. Short-term His infusion experiments also revealed negative effects of dHis supply below $1.8 \%$ (Ouellet et al., 2014) and 2.0\% of MP (Lapierre et al., 2014) on milk protein yield (MPY). Furthermore, the 
authors observed decreases in plasma carnosine (Car), blood hemoglobin $(\mathbf{H b})$ and muscle His-dipeptides compared with higher dHis supply treatments, suggesting a provision of His from these endogenous Hisreserves to sustain the metabolic needs (e.g., body protein, milk protein synthesis) of lactating cows. In addition to trends for lower DMI and decreased milk protein content and plasma His, Giallongo et al. (2016) also reported decreases in blood $\mathrm{Hb}$ in cows fed MPdeficient diets that provided dHis at $2.1 \%$ versus $2.4 \%$ of MP requirements. However, Giallongo et al. (2015) observed no effect of a MP-deficient diet (dHis at $2.0 \%$ vs. $2.3 \%$ of MP requirements) on plasma His and plasma and muscle His-dipeptides. Thus, it is not clear which components of the endogenous His reserves have the main role in providing His to lactating cows during dietary His deficiency. Based on the varying production responses observed in cows fed different levels of dietary dHis, the contribution of His by endogenous pools should be considered to better estimate His supply. In addition, the effects of His-deficiency have not been studied in long-term experiments in a diet providing adequate MP (NRC, 2001), Met, and Lys (Schwab et al., 2005).

Therefore, the objective of the present study was to evaluate the effects of feeding a His-deficient diet, based on assumed dHis requirements, on DMI, yields of milk and milk components, plasma metabolites and hormones, plasma and muscle free AA and His-dipeptides, and blood $\mathrm{Hb}$ in dairy cows. We hypothesized that feeding a His-deficient diet will have negative effects on DMI, yields of milk or milk components (or both), BW gain, N utilization, plasma His, and may decrease endogenous His-reserves (i.e., blood $\mathrm{Hb}$ and muscle His-dipeptides). We also hypothesized that supplementation of the His-deficient diet with rumen-protected (RP) His may alleviate these effects in dairy cows.

\section{MATERIALS AND METHODS}

\section{Cows and Experimental Design}

All procedures used in this experiment were approved by the Institutional Animal Care and Use Committee at The Pennsylvania State University. Twenty-four lactating Holstein cows (2 primiparous and 22 multiparous) averaging $( \pm \mathrm{SD}) 87 \pm 22 \mathrm{DIM}, 41.1 \pm 6.16 \mathrm{~kg} / \mathrm{d}$ of milk yield, $2 \pm 0.7$ lactations, and $630 \pm 56 \mathrm{~kg}$ of $\mathrm{BW}$ at the beginning of the experiment were involved in a randomized complete block design study conducted from August to November 2015. The duration of the experiment was $10 \mathrm{wk}$, including $2 \mathrm{wk}$ of covariate and an 8 -wk experimental period. The first $2 \mathrm{wk}$ of the experimental period were for diet adaptation. Cows were housed in the tie-stall barn of The Pennsylvania State University's Dairy Teaching and Research Center equipped with forced-air ventilation, and with individual rubber mats and water bowls (cows had free access to drinking water). All cows were adapted to the tie-stall barn for a week before the beginning of the experiment. During the covariate period, cows were fed the main herd diet, which consisted of (\% of DM) the following: 39.0 corn silage, 16.6 alfalfa haylage, 2.5 grass hay, 8.3 ground and 1.6 cracked corn, 7.5 solvent-extracted canola meal; 7.4 candy byproduct meal, 5.8 heat-treated whole soybeans, 5 cane molasses, 3.3 cottonseed hulls, 2.7 mineral and vitamin premix, and 0.3 Optigen (Alltech Inc., Nicholasville, KY). The covariate diet contained (\% of DM) $14.9 \mathrm{CP}, 31.2 \mathrm{NDF}, 21.9 \mathrm{ADF}$, and $44.4 \mathrm{NFC}$, and $1.56 \mathrm{Mcal} / \mathrm{kg}$ of $\mathrm{NE}_{\mathrm{L}}$. The 2 experimental diets (Table 1) were formulated using NRC (2001) to meet or exceed the nutrient requirements for lactating Holstein cows using averaged DMI $(26 \mathrm{~kg} / \mathrm{d})$, milk yield $(40.5 \mathrm{~kg} / \mathrm{d})$, milk composition ( $3.8 \%$ fat and $2.7 \%$ true protein), and BW $(630 \mathrm{~kg})$ of the cows during the covariate period. The His-adequate diet (HAD) was formulated to be adequate in dHis by including a His-rich feed ingredient (blood meal, BM; Table 1). The His-deficient diet (HDD) was formulated to be about 10 to $15 \%$ deficient in dHis, assuming dHis requirements of $2.2 \%$ of MP requirements (Lee et al., 2012), by replacing BM with hydrolyzed feather meal (FM; a His-poor feed ingredient). The HAD included more calcium salts of FA and urea because BM contained less ether extract and degradable protein, compared with FM. Both HAD and HDD were supplemented with RPMet (Mepron, Evonik Nutrition \& Care GmbH, Hanau, Germany) and RPLys (AjiPro-L, Ajinomoto Co. Inc., Tokyo, Japan) to meet recommended dMet and digestible Lys (dLys) concentration of 2.2 and $6.6 \%$ of MP requirements (Schwab et al., 2005), respectively. To meet the dMet and dLys requirements, the supplemental doses of RPMet and RPLys were adjusted weekly by calculating the dMet and dLys balances (NRC, 2001) using the actual DMI, milk yield and composition, and BW data of the cows during the previous week.

Cows were blocked by DIM, milk yield, and lactation number into 12 blocks of 2 cows per block, and cows within a block were randomly allocated to 1 of the 2 experimental diets (Table 1): (1) HAD [providing +166 $\mathrm{g} / \mathrm{d}$ over MP requirements according to NRC (2001) and dHis supply of $68 \mathrm{~g} / \mathrm{d}$, or $2.5 \%$ of MP requirements] and (2) HDD (providing $+37 \mathrm{~g} / \mathrm{d}$ over MP requirements and dHis supply of $49 \mathrm{~g} / \mathrm{d}$, or $1.9 \%$ of MP requirements).

The 2 diets were prepared using a Rissler model 1050 TMR mixer (I.H. Rissler Mfg. LLC, Mohnton, PA) and fed as TMR once daily at $0630 \mathrm{~h}$ for ad libitum intake. 
The TMR offered was adjusted daily to ensure about $10 \%$ refusals. The RPMet and RPLys products were fed mixed with the TMR. All cows were milked twice daily at 0630 and $1830 \mathrm{~h}$. At the end of the 10-wk experiment, the HDD group of cows was supplemented with $120 \mathrm{~g} /$ cow per day of RP L-His (Ajinomoto Co. Inc.; HDD+RPHis; same experimental product used in Giallongo et al., 2016) supplying $9.3 \mathrm{~g} / \mathrm{d}$ of dHis for

Table 1. Ingredient and chemical composition of the experimental diets fed in the study

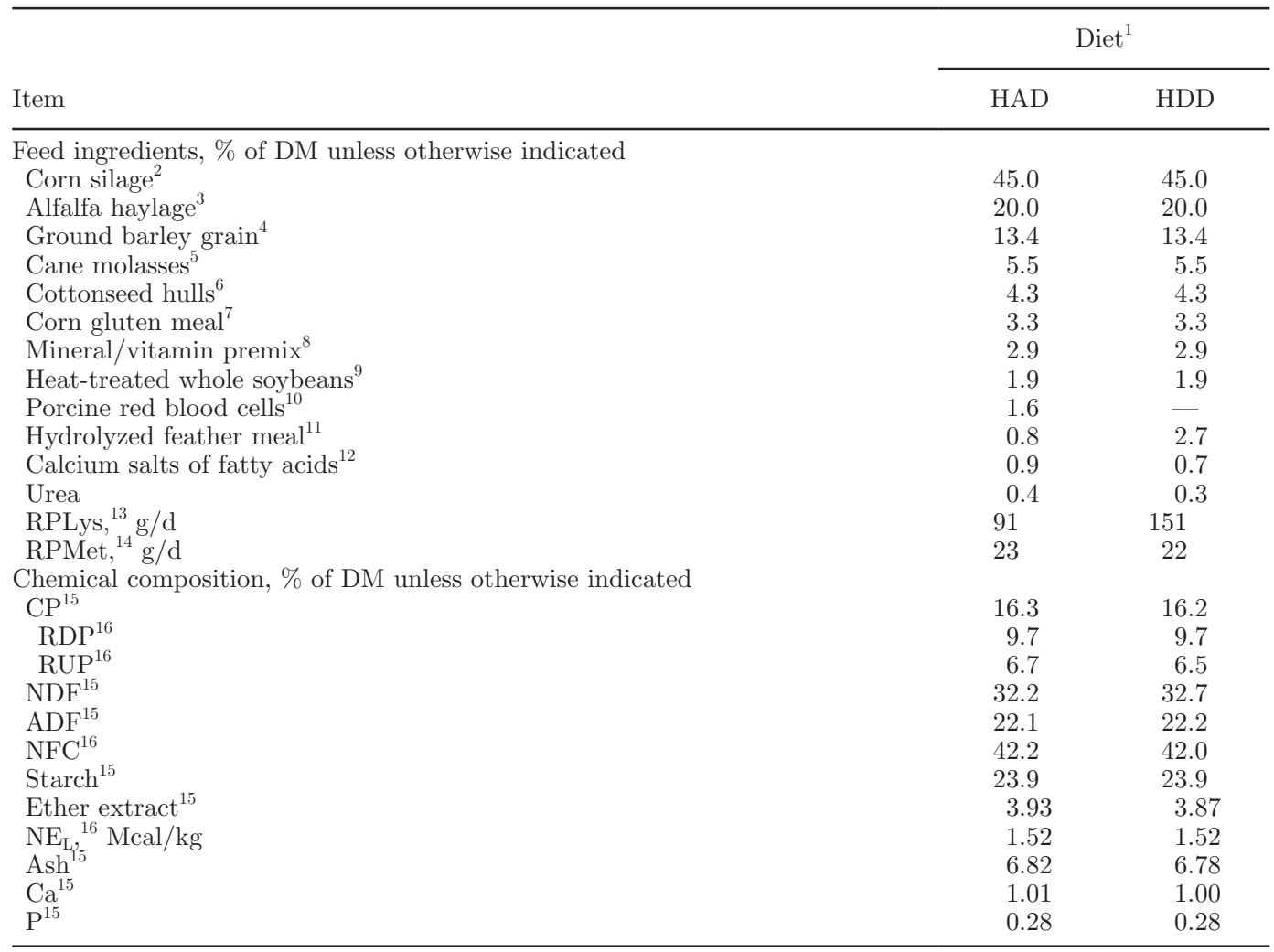

${ }^{1} \mathrm{HAD}=$ diet supplying digestible His at $2.5 \%$ of MP; HDD = diet supplying digestible His at $1.9 \%$ of MP.

${ }^{2}$ Corn silage was $39.3 \%$ DM and contained (DM basis) $6.6 \%$ CP, $51.1 \%$ NFC, 36.9\% starch, and 35.9\% NDF.

${ }^{3}$ Alfalfa haylage was $33.3 \% \mathrm{DM}$ and contained (DM basis) $19.8 \% \mathrm{CP}, 24.0 \% \mathrm{NFC}$, and $44.2 \% \mathrm{NDF}$.

${ }^{4}$ Ground barley grain contained (DM basis) $13.7 \%$ CP.

${ }^{5}$ Cane molasses (Westway Feed Products, Tomball, TX) contained (DM basis) 3.9\% CP and 66\% total sugar.

${ }^{6}$ Cottonseed hulls contained (DM basis) $7.8 \% \mathrm{CP}$.

${ }^{7}$ Corn gluten meal contained (DM basis) $69.3 \% \mathrm{CP}$.

${ }^{8}$ The mineral/vitamin premix (Cargill Animal Nutrition, Cargill Inc., Roaring Spring, PA) contained (\%, as-is basis) trace mineral mix, 0.86; $\mathrm{MgO}(56 \% \mathrm{Mg}), 8.0 ; \mathrm{NaCl}, 6.4$; vitamin ADE premix (Cargill Animal Nutrition, Cargill Inc.), 0.48; limestone, 37.2; selenium premix (Cargill Animal Nutrition, Cargill Inc.), 0.07; and dry corn distillers grains with solubles, 46.7. Ca, 14.1\%; P, 0.39\%; Mg, 4.60\%; K, 0.45\%; S, 0.38\%; Se, $6.67 \mathrm{mg} /$ $\mathrm{kg}$; Cu, $358 \mathrm{mg} / \mathrm{kg}$; Zn, 1,085 mg/kg; Fe, $188 \mathrm{mg} / \mathrm{kg}$, vitamin A, 262,656 IU/kg; vitamin D, 65,559 IU/kg; and vitamin E, 1,974 IU $/ \mathrm{kg}$.

${ }^{9}$ Heat-treated whole soybeans contained (DM basis) $40.3 \% \mathrm{CP}$.

${ }^{10}$ Porcine red blood cells (Innomax, Sonac USA LLC, Maquoketa, IA) contained (DM basis) 104\% CP. Rumen undegradable protein, $87.5 \%$ of CP; intestinal digestibility, $68.8 \%$ of RUP [determined in vitro according to Ross et al. (2013) by Cumberland Valley Analytical Services (Maugansville, MD)].

${ }^{11}$ Hydrolyzed feather meal (Darling Ingredients Inc., Irving, TX) contained (DM basis) $91.6 \%$ CP. Rumen undegradable protein, $86.5 \%$ of CP; intestinal digestibility, $20.2 \%$ of RUP [determined in vitro according to Ross et al. (2013) by Cumberland Valley Analytical Services].

${ }^{12}$ Calcium salts of fatty acids (Megalac, Church \& Dwight Co. Inc., Princeton, NJ) contained (DM basis) $84.5 \%$ ether extract.

${ }^{13}$ Rumen-protected (RP) Lys (AjiPro-L, Ajinomoto Co. Inc., Tokyo, Japan).

${ }^{14}$ Rumen-protected (RP) Met (Mepron, Evonik Nutrition \& Care GmbH, Hanau, Germany).

${ }^{15}$ Values calculated using the chemical analysis (Cumberland Valley Analytical Services Inc.) of individual feed ingredients of the diet.

${ }^{16}$ Values estimated based on NRC (2001). 
an additional $9 \mathrm{~d}$ (wk 11). The goal of this supplementation was to evaluate the potential positive effect of His on DMI. The HDD+RPHis diet provided +111 $\mathrm{g} / \mathrm{d}$ over MP requirements (NRC, 2001) and $61 \mathrm{~g} / \mathrm{d}$ of total dHis supply (i.e., $2.4 \%$ of MP requirements). The RPHis product was fed top-dressed, mixed with a small portion of the TMR immediately after it was delivered to the feed bunk. Supply of dMet, dLys, and dHis from the 3 RPAA (i.e., RPMet, RPLys, and RPHis, respectively) were determined as described in Giallongo et al. (2016). Briefly, the supply of dAA was determined from the analyzed AA concentration and bioavailability of AA from the 3 RPAA $(69,54$, and $18 \%$ for RPMet, RPLys, and RPHis, respectively) estimated from the rumen escape determined in an in situ experiment (Giallongo et al., 2016) and intestinal digestibility data provided by the manufacturers.

\section{Sampling and Measurements}

Milk yield and TMR fed and refusals (on as-fed basis) of individual cows were recorded daily during the entire experiment. Cows were individually weighed on 2 consecutive mornings at $0530 \mathrm{~h}$ (before milking and feeding) during wk 2 of the covariate period and then biweekly throughout the experimental period (i.e., total of 10 measurements). Cow BW for a given week of the study was determined by averaging the BW measured on the 2 consecutive mornings. Body condition score was evaluated twice during the experiment (wk 2 of the covariate period and wk 10 of the experiment) by one trained person using a 5-point scale (Edmonson et al., 1989).

Refusals and TMR samples from HAD and HDD were collected twice weekly and composited (equal weight basis) by week and diet, whereas individual feed ingredients samples were collected weekly. All samples were stored at $-20^{\circ} \mathrm{C}$, and then dried at $55^{\circ} \mathrm{C}$ for $72 \mathrm{~h}$ in a forced-air oven for DM determination. Daily DMI was calculated from the as-fed TMR intake using the DM content of the weekly composited refusals and TMR samples. All samples were ground using a Wiley Mill through a 1-mm screen (Thomas Scientific, Swedesboro, NJ), and one composite sample (equal weight basis) for the entire experiment was prepared for each TMR and individual feed ingredients for further analysis.

Composited TMR samples were analyzed for indigestible NDF (iNDF) as described by Lee et al. (2012). Composited feed ingredients samples were analyzed by wet chemistry methods for CP, NDF, ADF, starch, ether extract, ash, $\mathrm{Ca}, \mathrm{P}$, and estimated $\mathrm{NFC}$ and $\mathrm{NE}_{\mathrm{L}}$ by Cumberland Valley Analytical Services (CVAS; Maugansville, MD; methods are available at http:// www.foragelab.com/Resources/Lab-Procedures, ac- cessed September 11, 2016) and for AA (AOAC International, 1995; European Commission, 2009) by Evonik Nutrition \& Care GmbH. Samples of porcine red blood cells (BM) and FM were also analyzed for in vitro RUP and intestinal digestibility of RUP by CVAS following the procedure of Ross et al. (2013).

The chemical composition of the diets (i.e., CP, NDF, $\mathrm{ADF}$, starch, ether extract, ash, Ca, and $\mathrm{P}$; Table 1) was calculated from the analyzed composition of the individual feed ingredients and their inclusion in HAD and HDD. The RDP, RUP, NFC, and $\mathrm{NE}_{\mathrm{L}}$ concentrations of the diets (Table 1), $\mathrm{NE}_{\mathrm{L}}$ and protein fraction balances, and AA supplies (Table 2) were estimated based on NRC (2001) using the analyzed composition of the feed ingredients and the cow data (i.e., DMI, milk yield and composition, and BW) during the last 6 wk of the experimental period.

The AA balances (dHis, dMet, and dLys; Table 2) were calculated as the sum of the supply of dAA from the diet (NRC, 2001) and from supplemental RPAA minus assumed requirements (as described above). The $\mathrm{N}$ content and bioavailability data of the supplemented RPMet and RPLys (estimated in Giallongo et al., 2016) were used in the calculation of $\mathrm{CP}$ content of the diets and protein fractions and AA balances.

Milk samples were collected at 2 consecutive milkings (p.m. and a.m.) on d 3 and 4 of wk 2 of the covariate period, weekly throughout the 8 -wk experimental period, and during wk 11 (i.e., on d 8 and 9 , as described above) for the HDD+RPHis cows only. Milk samples were preserved with 2-bromo-2-nitropropane-1,3-diol and analyzed for fat, true protein, lactose, and MUN (AOAC International, 2012; method 972.16) using a MilkoScan FT+ analyzer (Foss, Eden Prairie, MN) by Dairy One Cooperative Inc. (Ithaca, NY). Milk composition data were weighted for the corresponding milk yield (i.e., p.m. or a.m. milkings), averaged by sampling week, and the average values were used in the statistical analysis. An additional set of milk samples was collected in tubes without preservative (again from p.m. and a.m. milkings) during wk 9 and 10 of the experiment and stored at $-20^{\circ} \mathrm{C}$ until FA composition analysis as described by Rico and Harvatine (2013).

During wk 9 of the experiment, 8 spot urine and fecal samples (approximately $300 \mathrm{~mL}$ and $500 \mathrm{~g} /$ sample, respectively) were collected from all cows on 3 consecutive days (at 1000, 1600, and $2200 \mathrm{~h}$ on d 2;0400, 1300, and $1900 \mathrm{~h}$ on d 3; and 0100 and $0800 \mathrm{~h}$ on d 4). Urine samples were processed and one composite sample per cow was analyzed for urea- $\mathrm{N}$, total $\mathrm{N}$, creatinine, and purine derivatives (PD; allantoin and uric acid) as described in Lee et al. (2012).

Fecal samples were oven-dried at $65^{\circ} \mathrm{C}$ for $48 \mathrm{~h}$, ground through a 1-mm sieve, and one composite 
sample per cow was analyzed for DM, OM, CP, NDF, $\mathrm{ADF}$, and iNDF as described in Lee et al. (2012) and for starch according to Hall (2009). Daily urine volume was estimated using creatinine as a marker, assuming

Table 2. Net energy of lactation, protein fractions, and AA supply and balance ${ }^{1}$ in dairy cows fed His-deficient and His-adequate diets

\begin{tabular}{|c|c|c|}
\hline \multirow[b]{2}{*}{ Item } & \multicolumn{2}{|c|}{$\operatorname{Diet}^{2}$} \\
\hline & HAD & HDD \\
\hline \multicolumn{3}{|l|}{$\mathrm{NE}_{\mathrm{L}}, \mathrm{Mcal} / \mathrm{d}$} \\
\hline Requirements & 38.2 & 36.6 \\
\hline Supply & 41.0 & 38.3 \\
\hline Balance & 2.8 & 1.7 \\
\hline \multicolumn{3}{|l|}{ Protein fraction balance, ${ }^{3} \mathrm{~g} / \mathrm{d}$} \\
\hline \multicolumn{3}{|l|}{ MP } \\
\hline Requirements & 2,699 & 2,519 \\
\hline Supply & 2,864 & 2,556 \\
\hline Balance & 166 & 37 \\
\hline \multicolumn{3}{|l|}{ RDP and RUP } \\
\hline RDP supply & 2,627 & 2,475 \\
\hline RDP balance & 16 & -14 \\
\hline RUP supply & 1,777 & 1,674 \\
\hline RUP balance & 224 & 56 \\
\hline \multicolumn{3}{|l|}{$\begin{array}{l}\text { AA balance, }{ }^{3,4} \mathrm{~g} / \mathrm{d} \\
\text { dHis }\end{array}$} \\
\hline Suggested requirements ${ }^{4}$ & 59 & 55 \\
\hline Supply from the diet & 68 & 49 \\
\hline Balance & 9 & -6 \\
\hline \multicolumn{3}{|l|}{ dMet } \\
\hline Requirements ${ }^{4}$ & 59 & 55 \\
\hline Supply from the diet & 52 & 48 \\
\hline Supply from RPMet ${ }^{5}$ & 14 & 13 \\
\hline Balance & 7 & 6 \\
\hline \multicolumn{3}{|l|}{ dLys } \\
\hline Requirements ${ }^{4}$ & 178 & 166 \\
\hline Supply from the diet & 174 & 147 \\
\hline Supply from RPLys ${ }^{5}$ & 19 & 32 \\
\hline Balance & 15 & 13 \\
\hline \multicolumn{3}{|c|}{ Other AA supplied from the diet, $\mathrm{g} / \mathrm{d}$} \\
\hline dArg & 121 & 106 \\
\hline dIle & 128 & 122 \\
\hline dLeu & 287 & 248 \\
\hline dPhe & 147 & 128 \\
\hline dThr & 132 & 120 \\
\hline dVal & 161 & 138 \\
\hline Total digestible EAA & 1,270 & 1,106 \\
\hline
\end{tabular}

${ }^{1}$ All values were estimated using NRC (2001) based on actual averaged DMI, milk yield and composition, and BW of individual cows during wk 5 to 10

${ }^{2} \mathrm{HAD}=$ diet supplying digestible His at $2.5 \%$ of MP; HDD = diet supplying digestible His at $1.9 \%$ of MP.

${ }^{3}$ Due to rounding, balance may not exactly match requirements and supply; dHis, dMet, and dLys = digestible His, Met, and Lys, respectively.

${ }^{4}$ Requirements of dHis, dMet, and dLys were calculated as 2.2, 2.2, and $6.6 \%$ (respectively) of MP requirements (for details see Materials and Methods section).

${ }^{5}$ Supply of digestible Met and Lys from rumen-protected Met (RPMet) and rumen-protected Lys (RPLys), respectively, were determined by Giallongo et al. (2016) from the analyzed Met and Lys content of the products, rumen escape determined in situ, and intestinal digestibility data provided by the manufacturers: $86 \%$ Met and $69 \%$ bioavailability (77\% rumen escape and 90\% intestinal digestibility; RPMet), 39\% Lys and $54 \%$ bioavailability ( $88 \%$ rumen escape and $62 \%$ intestinal digestibility; RPLys). a creatinine excretion rate of $29 \mathrm{mg} / \mathrm{kg}$ of $\mathrm{BW}$ (see Hristov et al., 2011), and was used to estimate excretions of urinary urea-N, total N, and PD. Apparent total-tract digestibility of nutrients (i.e., DM, OM, $\mathrm{CP}, \mathrm{NDF}, \mathrm{ADF}$, and starch) was calculated based on iNDF as an internal digestibility marker (Schneider and Flatt, 1975).

Blood samples were collected from the tail vein or artery of the cows into $10-\mathrm{mL}$ Vacutainer $\mathrm{K}_{2}$ EDTA tubes (Becton, Dickinson and Company, Franklin Lakes, NJ) at $3 \mathrm{~h}$ after feeding on $\mathrm{d} 3$ during wh 2 of the covariate period, weekly throughout the 8-wk experimental period, and on d 8 during wk 11 for HDD+RPHis cows only (i.e., total of 10 sampling events). These samples were analyzed (within $3 \mathrm{~h}$ after collection) for $\mathrm{Hb}$ concentration using a HEMAVET 950FS hematology analyzer (Drew Scientific Inc., Oxford, CT). Additional sets of blood samples were collected 4 times in 2 consecutive days (at 3 and $9 \mathrm{~h}$ after feeding on $\mathrm{d} 3$ and at 6 and $12 \mathrm{~h}$ after feeding on d 4; i.e., 4 samples/cow per wk) during wk 2 of the covariate period and wk 4 and 9 of the experiment, and on $\mathrm{d} 7$ and 8 during wk 11 for the HDD+RPHis cows only. Blood plasma was separated by centrifugation $\left(1,500 \times g\right.$ for $15 \mathrm{~min}$ at $\left.4^{\circ} \mathrm{C}\right)$ and stored at $-20^{\circ} \mathrm{C}$ until further analysis. Composited (i.e., per cow and week on an equal-volume basis) plasma samples were analyzed for urea-N (Stanbio Urea Nitrogen Kit 580; Stanbio Laboratory Inc., Boerne, TX), creatinine (QuantiChrom Creatinine assay kit, DICT-500; BioAssays Systems, Hayward, CA), glucose (Stanbio Glucose kit 1070; Stanbio Laboratory Inc.), nonesterified fatty acids (NEFA; HR Series NEFA-HR (2), Wako Life Sciences Inc., Mountain View, CA), leptin (RIA kit XL85K, EMD Millipore Corp., Billerica, MA), and insulin (RIA kit PI-12K, EMD Millipore Corp.). Composite plasma samples were also analyzed for AA and Car as follows: samples from wk 2 of the covariate period and wk 4 and 9 were analyzed by Evonik Nutrition \& Care $\mathrm{GmbH}$ as described above for feed ingredient samples. Additionally, samples from wk 9 and 11 were analyzed for AA and Car at the University of MissouriColumbia's Agricultural Experiment Station Chemical Laboratories (Columbia, MO) following the procedures of Deyl et al. (1986) and Fekkes (1996).

Muscle biopsies of the longissimus dorsi were obtained from all cows during wk 10 of the experiment as described in Giallongo et al. (2015), except at least $1 \mathrm{~g}$ of muscle tissue sample per cow was collected. Muscle samples were homogenized in ice-cold buffer as described by Lang et al. (2013), and then analyzed for concentrations of free AA and His-dipeptides [Car and anserine (Ans)] at the University of Missouri-Columbia's Agricultural Experiment Station Chemical Laboratories. 


\section{Statistical Analysis}

All data were assessed for outliers and normality, and analyzed using PROC MIXED of SAS (release 9.4, SAS Institute Inc., Cary, NC). Outliers were removed using the REG procedure based on an absolute studentized residual value $>3$. Data were assessed for normality using the UNIVARIATE procedure and log-transformed when the null hypothesis of normality was rejected $(P$ $<0.05$ and small Shapiro-Wilk $W$ statistic). Data (i.e., wk 5 to 10) for DMI, milk yield and milk composition, feed efficiency (milk yield $\div$ DMI), and BW were averaged by week, and including blood $\mathrm{Hb}$ data were analyzed with week as repeated measures. The statistical model included treatment, week, treatment $\times$ week interaction, and the covariate term. Treatment, week, and treatment $\times$ week were fixed effects, whereas block and treatment $\times$ block were random. All other data (i.e., BW change and BCS, milk FA, nutrient intake and digestibility, urinary and fecal $\mathrm{N}$ excretion, and plasma metabolites, hormones, and AA, and muscle free AA were analyzed with the above-described model excluding week and treatment $\times$ week interaction. Of the additional $9 \mathrm{~d}$ data collected (i.e., wk 11) for HDD+RPHis, the last $6 \mathrm{~d}$ were used in the statistical analysis. Significance was declared at $P \leq 0.05$, tendencies at $0.05<P \leq 0.10$. Data are expressed as least squares means or covariate-adjusted least squares means.

\section{RESULTS}

The 2 experimental diets had similar nutrient composition (Table 1) and supplied adequate $\mathrm{NE}_{\mathrm{L}}$, MP, and RUP relative to the cow requirements (based on NRC, 2001; Table 2). The HAD was adequate in RDP, whereas HDD was slightly deficient (i.e., $-14 \mathrm{~g} / \mathrm{d}$ ). According to Lee et al. (2012), HAD met the estimated dHis requirements, whereas HDD was $11 \%$ deficient in dHis. Both HAD and HDD provided dMet and dLys in excess of the requirements according to Schwab et al. (2005). The supply of all other digestible EAA (dEAA) as predicted by NRC (2001) is also reported in Table 2 .

Dry matter intake, yields of milk and milk lactose, MPY, ECM, milk $\mathrm{NE}_{\mathrm{L}}$, and MUN were decreased $(P \leq$ 0.02 ) by HDD compared with HAD (Table 3 ). Milk fat yield was not different $(P=0.12)$ between treatments. Feed and ECM feed efficiencies, milk fat, true protein and lactose concentrations, SCC, BW and BW change, and BCS of the cows were not affected by treatments.

The time-course of DMI during the covariate wk 1 to 2, wk 5 to 10 , and wk 11, during which the HDD diet was supplemented with RPHis, are also shown in Figure 1. Dry matter intake was not different (average of 26.1 vs. $26.1 \mathrm{~kg} / \mathrm{d}, P=0.99$ ) between HAD and HDD cows during the covariate period, and was lower for HDD compared with HAD during wk 5 to 10 (average of 25.4 vs. $27.1 \mathrm{~kg} / \mathrm{d} ; P<0.01$ ). Supplementation of HDD with RPHis during wk 11 increased DMI, compared with HDD during wk 5 to 10 of the study (average of 26.8 vs. $25.4 \mathrm{~kg} / \mathrm{d}$, respectively; $P<0.01$ ).

Addition of RPHis to HDD during wk 11 did not affect milk yield, whereas ECM yield ( 34.2 vs. $32.2 \mathrm{~kg} / \mathrm{d}$; $P=0.06$; data not shown) tended to be increased, compared with HDD during wk 10 of the study.

Concentrations of FA in milk are presented in Table 4. Concentrations of 8:0 and 14:0 iso tended or were decreased ( $P=0.09$ and 0.05 , respectively) by HDD compared with HAD. Concentrations of 16:0 tended to be increased $(P=0.08)$ by HDD versus HAD. Concentrations of other milk FA were not affected by diet.

During the urine and fecal sampling wk (i.e., wk 9 of the experiment), NDF intake tended to be lower $(P=$ 0.06 ) with HDD compared with HAD (Table 5). Apparent total-tract digestibilities of DM, OM, CP, and NDF were decreased $(P \leq 0.03)$ by HDD versus HAD. Intake and digestibility of ADF and starch digestibility were not affected by diet.

Intake of $\mathrm{N}$ was not affected $(P=0.13)$ by treatment and milk true protein $\mathrm{N}$ secretion tended to be decreased $(P=0.07)$ by HDD compared with HAD (Table 6). Excretion of urinary $\mathrm{N}$ and urea-N were lower $(P<0.01)$ for HDD versus HAD. Urine and fecal DM outputs, excretions of urinary urea-N as a proportion of total urinary $\mathrm{N}$, fecal $\mathrm{N}$ excretion, and total $\mathrm{N}$ losses with urine, feces, and milk (including as a proportion of $\mathrm{N}$ intake) were not affected by treatment. As a proportion of $\mathrm{N}$ intake, milk true protein $\mathrm{N}$ secretion was not affected $(P=0.12)$ by treatment, urinary $\mathrm{N}$ excretion was decreased $(P=0.01)$, and fecal N excretion was increased $(P<0.01)$, respectively, for HDD versus HAD. Urinary excretion of uric acid tended to be decreased $(P=0.10)$ by HDD versus HAD, whereas urinary excretion of allantoin and total PD were not different between diets.

Concentration of plasma urea- $\mathrm{N}$ was decreased $(P=$ $0.01)$, and leptin tended to be decreased $(P=0.06)$ by HDD compared with HAD (Table 7). Plasma creatinine, glucose, NEFA, and insulin concentrations were not affected by diet.

The HDD decreased plasma concentrations of His, Leu, Lys, Val, and Car $(P \leq 0.02)$, and increased plasma Tau $(P=0.01)$, respectively, compared with HAD (Table 8). Plasma Ile tended to increase $(P=0.07)$ and total EAA tended to decrease $(P=0.06)$, respectively, with HDD versus HAD. Concentrations of the remaining AA were not different between diets.

Concentrations of plasma His $(21.1$ vs. $65.4 \mu M ; P$ $<0.01)$ and Car (9.38 vs. $11.9 \mu M ; P<0.01)$ were 
MP. Similarly, in Giallongo et al. (2016), DMI tended to be lower in cows fed diets with dHis at $2.1 \%$ versus $2.4 \%$ of MP. Short-term infusion studies also reported decreases in DMI of dairy cows fed diets supplying dHis below 2.5\% (Ouellet et al., 2014) and 2.3\% of MP (Lapierre et al., 2014). An adverse effect of reducing dietary His concentrations on voluntary feed intake have also been described in nonruminant species (see discussions in Giallongo et al., 2015, 2016). Other studies (Korhonen et al., 2000; Kim et al., 2001; Huhtanen et al., 2002) have not observed a negative effect of lowHis diets on DMI of dairy cows, although the method of feeding (grass silage ad libitum and concentrate in fixed amounts) may have affected the DMI response of the cows (i.e., the increase in DMI could arise only from grass silage). Based on the results of the current experiment, along with the above-mentioned studies, the recommended concentration of dHis in MP (i.e., $2.2 \%$ of MP requirements; Lee et al., 2012) may not be sufficient to maximize the stimulatory effect of His on DMI of lactating dairy cows. Thus, further research is needed to elucidate the long-term effects of diets providing increasing concentrations of dHis on DMI of lactating dairy cows.

The HDD provided lower amounts of other dEAA (i.e., Arg, Ile, Leu, Lys, Met, Phe, Thr, and Val; as estimated using NRC, 2001) because of the decreased DMI

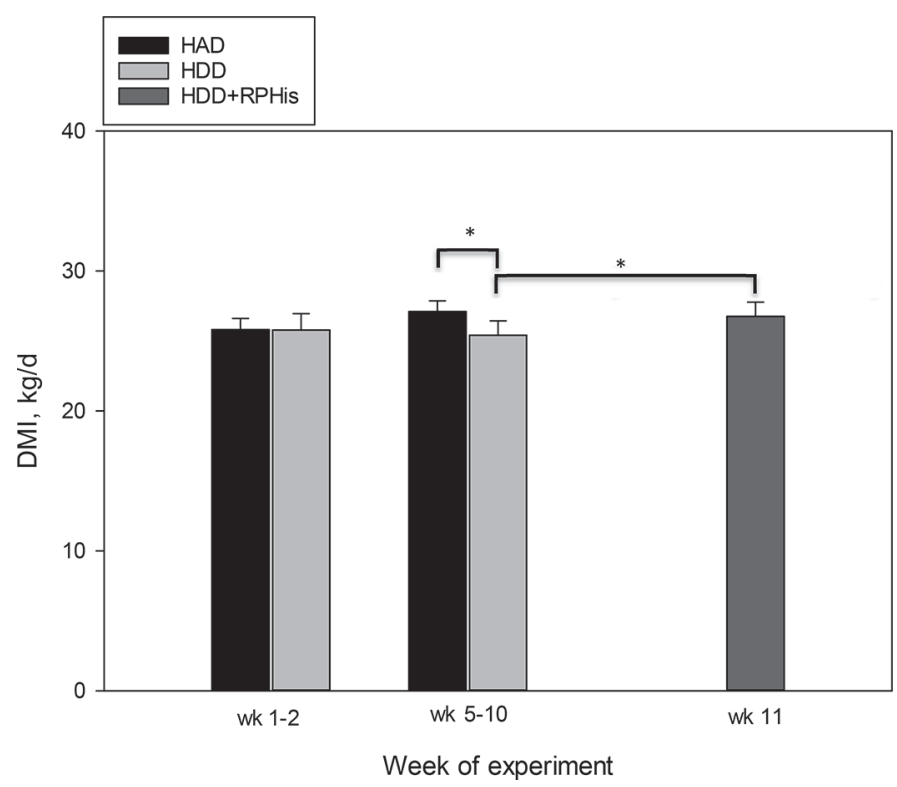

Figure 1. Dry matter intake (mean \pm SEM) during wk 1 to 2 (covariate period) and wk 5 to 10 of the experiment in dairy cows fed a diet supplying digestible His (dHis) at $2.5 \%$ of MP (HAD) or a diet supplying dHis at $1.9 \%$ of MP (HDD). In wk 11, the HDD diet was supplemented with rumen-protected (RP) His (see Materials and Methods). Significant differences between HAD and HDD and between HDD and HDD+RPHis are denoted as $* P \leq 0.01$. of HDD cows, a lower concentration of some of these EAA in HDD versus HAD, and lower RUP digestibility of FM than BM. However, the lower DMI of HDD cows cannot be attributed to the decreased supply of dMet and dLys because these $2 \mathrm{AA}$ have not been shown to stimulate DMI of dairy cows when supplied at higher concentrations than those provided by HDD (i.e., 2.4 and $7.1 \%$ of MP requirements, respectively; Varvikko et al., 1999; Robinson et al., 2000). Supplementation of the other dEAA such as Arg (Vicini et al., 1988), Ile and Val (Korhonen et al., 2002), Leu (Rulquin and Pisulewski, 2006), Phe (Swanepoel et al., 2016), and Thr (Schwab et al., 1976), at least within the range provided by HDD and HAD in the present experiment, has not been reported to affect DMI in lactating dairy cows. Indeed, at the end of the current study, addition of RPHis to HDD during wk 11 increased DMI by 1.4 kg compared with HDD (during wk 5-10), which was accompanied by a simultaneous increase in plasma His. A similar positive relation between DMI and plasma His was observed in our previous study (Giallongo et al., 2016) and a meta-analysis (Patton et al., 2015).

A negative effect of high dietary inclusions (\% of DM) of FM, compared with the present study, on DMI of lactating cows was observed in some studies (4 and $8 \%$, Moss et al., $1995 ; 6 \%$ in early/mid lactating cows, Yeo et al., 2003), but not in others (3 and 6\%, Harris et al., 1992; 3.4\%, Tomlinson et al., 1994; 6.7\% in mid/ late lactating cows, Yeo et al., 2003).

Overall, although the lower palatability of FM compared with other feed ingredients cannot be ignored, particularly at high inclusion levels in the diet (e.g., $12.6 \%$ of diet DM, Stahel et al., 2014), data from the current study suggest His deficiency as the cause for the decreased DMI in cows receiving HDD.

Milk and ECM yields were decreased by about $3 \mathrm{~kg} / \mathrm{d}$ for HDD compared with HAD. These results are in line with the observed DMI of the cows and the consequent lack of difference in feed and ECM feed efficiencies between the 2 diets. Milk protein yield was also decreased for HDD compared with HAD. The adverse effects of HDD on these production variables are explained by the lower DMI and total supply of dEAA (particularly dHis), compared with HAD (Giallongo et al., 2016).

Fraser et al. (1991) reported decreased milk yield and MPY in dairy cows when His was removed from the AA infusion mix. Later studies reported lower milk yield and MPY in dairy cows fed His-deficient diets based on grass silage (Kim et al., 1999; Vanhatalo et al., 1999; Huhtanen et al., 2002). Similar negative effects of feeding a His-poor feed (FM) were observed in a greater extent in diets with higher levels of His-deficiency (Kim et al., 1999; Yeo et al., 2003), and in diets with lower CP content (Tomlinson et al., 1994) and thus more likely to 
supply dHis and other dEAA (e.g., Met and Lys) below cows requirements for milk production. Lapierre et al. (2014) and Ouellet et al. (2014) observed an adverse effect of decreasing dHis supply on milk yield and MPY of dairy cows. Similarly, a decrease in milk yield and MPY with lower dHis supply was reported in a metaanalysis by Patton et al. (2015). A negative effect of
His-deficiency on MPY was also observed in cows fed reduced-protein diets (Giallongo et al., 2015).

As discussed above, HDD supplied lower amounts of other individual dEAA (i.e., Arg, Ile, Leu, Phe, Thr, and Val). However, even large decreases in the supply of these dEAA (Arg, Ile, Leu, and Val, Schwab et al., 1976; Huhtanen et al., 2002; Korhonen et al.,

Table 4. Effects of dietary His supply on milk FA composition (g/100 g of total FA) in dairy cows

\begin{tabular}{|c|c|c|c|c|}
\hline \multirow[b]{2}{*}{ Item } & \multicolumn{2}{|c|}{ Diet $^{1}$} & \multirow[b]{2}{*}{$\mathrm{SEM}^{2}$} & \multirow[b]{2}{*}{$P$-value } \\
\hline & HAD & HDD & & \\
\hline $4: 0$ & 4.25 & 4.04 & 0.123 & 0.24 \\
\hline $6: 0$ & 2.23 & 2.10 & 0.061 & 0.16 \\
\hline $8: 0$ & 1.22 & 1.13 & 0.035 & 0.09 \\
\hline 10:0 & 2.76 & 2.59 & 0.087 & 0.17 \\
\hline 11:0 & 0.05 & 0.06 & 0.003 & 0.57 \\
\hline $12: 0$ & 3.22 & 3.07 & 0.094 & 0.29 \\
\hline 13:0 & 0.10 & 0.10 & 0.005 & 0.71 \\
\hline $14: 0$ & 11.0 & 10.6 & 0.209 & 0.24 \\
\hline 14:0 iso & 0.10 & 0.07 & 0.009 & 0.05 \\
\hline $14: 1$ & 0.95 & 0.94 & 0.048 & 0.93 \\
\hline 15:0 & 1.02 & 1.07 & 0.040 & 0.35 \\
\hline 15:0 iso & 0.18 & 0.17 & 0.004 & 0.32 \\
\hline 15:0 anteiso & 0.38 & 0.36 & 0.012 & 0.40 \\
\hline $16: 0$ & 32.3 & 34.0 & 0.656 & 0.08 \\
\hline 16:0 iso & 0.21 & 0.17 & 0.018 & 0.11 \\
\hline $16: 1$ & 1.38 & 1.54 & 0.083 & 0.17 \\
\hline $17: 0$ & 0.52 & 0.54 & 0.012 & 0.32 \\
\hline 17:0 iso & 0.19 & 0.18 & 0.006 & 0.22 \\
\hline 17:0 anteiso & 0.38 & 0.37 & 0.014 & 0.36 \\
\hline $17: 1$ & 0.19 & 0.20 & 0.009 & 0.47 \\
\hline 18:0 & 9.05 & 9.04 & 0.352 & 0.97 \\
\hline trans-4 18:1 & 0.03 & 0.03 & 0.001 & 0.47 \\
\hline trans-6,8 18:1 & 0.32 & 0.30 & 0.014 & 0.35 \\
\hline trans-9 18:1 & 0.24 & 0.24 & 0.009 & 0.77 \\
\hline trans-10 18:1 & 0.48 & 0.49 & 0.074 & 0.93 \\
\hline trans-11 18:1 & 0.76 & 0.72 & 0.041 & 0.48 \\
\hline trans-12 18:1 & 0.53 & 0.53 & 0.017 & 0.97 \\
\hline trans-15 18:1 & 0.31 & 0.30 & 0.007 & 0.66 \\
\hline cis-9 18:1 & 17.9 & 17.3 & 0.355 & 0.21 \\
\hline cis-11 18:1 & 0.65 & 0.70 & 0.052 & 0.49 \\
\hline cis-12 18:1 & 0.42 & 0.41 & 0.019 & 0.71 \\
\hline cis-9,cis-12 18:2 & 2.59 & 2.50 & 0.108 & 0.58 \\
\hline $18: 3$ & 0.37 & 0.35 & 0.017 & 0.40 \\
\hline $20: 0$ & 0.13 & 0.14 & 0.005 & 0.30 \\
\hline $20: 1$ & 0.05 & 0.05 & 0.002 & 0.55 \\
\hline cis-9,trans-11 CLA & 0.42 & 0.41 & 0.021 & 0.65 \\
\hline $22: 0$ & 0.05 & 0.05 & 0.002 & 0.34 \\
\hline $20: 3$ & 0.12 & 0.11 & 0.004 & 0.64 \\
\hline $20: 4$ & 0.18 & 0.17 & 0.007 & 0.31 \\
\hline $24: 0$ & 0.03 & 0.03 & 0.002 & 0.80 \\
\hline $22: 5$ & 0.06 & 0.06 & 0.003 & 0.79 \\
\hline Others & 2.65 & 2.71 & 0.059 & 0.47 \\
\hline $\mathrm{OBCFA}^{3}$ & 3.27 & 3.23 & 0.057 & 0.68 \\
\hline OBCFA, g/d & 46.8 & 43.8 & 2.547 & 0.41 \\
\hline$\Sigma \mathrm{SFA}$ & 69.3 & 69.8 & 0.647 & 0.56 \\
\hline$\Sigma$ MUFA & 24.2 & 23.8 & 0.507 & 0.51 \\
\hline$\Sigma$ PUFA & 3.80 & 3.68 & 0.144 & 0.59 \\
\hline$\Sigma$ trans $18: 1$ & 2.68 & 2.63 & 0.134 & 0.79 \\
\hline
\end{tabular}

${ }^{1} \mathrm{HAD}=$ diet supplying digestible His at $2.5 \%$ of MP; HDD = diet supplying digestible His at $1.9 \%$ of MP.

${ }^{2}$ Largest SEM published in table, $\mathrm{n}=23$ to 24 (n represents number of observations used in the statistical analysis). Data in this table are for wk 9 and 10 when milk samples for FA analysis were collected.

${ }^{3}$ Odd- and branched-chain fatty acids $=$ sum of odd- (13:0, 15:0, 17:0, 17:1) and branched-chain (14:0 iso, 15:0 iso, 16:0 iso, 17:0 iso, 15:0 anteiso, 17:0 anteiso) fatty acids. 
Table 5. Effects of dietary His supply on intake and apparent total-tract digestibility of nutrients in dairy cows

\begin{tabular}{lcccc}
\hline & \multicolumn{2}{c}{ Diet $^{1}$} & & \\
\cline { 2 - 3 } Item & HAD & HDD & SEM $^{2}$ & $P$-value \\
\hline Nutrient intakes, kg/d & & & & \\
DM & 28.1 & 26.4 & 0.87 & 0.16 \\
OM & 26.4 & 24.7 & 0.81 & 0.16 \\
CP & 4.59 & 4.27 & 0.141 & 0.13 \\
NDF & 9.17 & 8.38 & 0.278 & 0.06 \\
ADF & 6.00 & 5.91 & 0.190 & 0.74 \\
Starch & 6.74 & 6.31 & 0.207 & 0.16 \\
Apparent digestibility, \% & & & & 0.03 \\
DM & 66.1 & 64.8 & 0.41 & 0.03 \\
OM & 67.6 & 66.2 & 0.40 & $<0.01$ \\
CP & 63.1 & 57.2 & 0.81 & 0.02 \\
NDF & 43.5 & 41.0 & 0.68 & 0.88 \\
ADF & 36.8 & 36.6 & 1.01 & 0.90 \\
Starch & 98.2 & 98.2 & 0.17 & 0.9 \\
\hline
\end{tabular}

${ }^{1} \mathrm{HAD}=$ diet supplying digestible His at $2.5 \%$ of MP; HDD = diet supplying digestible His at $1.9 \%$ of MP.

${ }^{2}$ Largest SEM published in table; $\mathrm{n}=24$ ( $\mathrm{n}$ represents number of observations used in the statistical analysis).

Data in this table are for wk 9 when urine and fecal samples were collected.

2002; Haque et al., 2013; Thr, Doepel et al., 2016), compared with HDD in the present study, had no effects on yields of milk and milk protein and fat in dairy cows. In contrast, studies with larger deficiencies of Leu (Rulquin and Pisulewski, 2006), Phe (Doelman et al.,
2015; Doepel et al., 2016), and Val (Haque et al., 2013), compared with HDD in this experiment, resulted in decreased MPY. In the present study, compared with HDD (data from wk 10 of the study), supplementation of HDD with RPHis did not affect milk yield. However,

Table 6. Effects of dietary His supply on milk $\mathrm{N}$ secretion and excretion of urinary and fecal $\mathrm{N}$ and urinary purine derivatives $(\mathrm{PD})$ in dairy cows

\begin{tabular}{|c|c|c|c|c|}
\hline \multirow[b]{2}{*}{ Item } & \multicolumn{2}{|c|}{$\operatorname{Diet}^{2}$} & \multirow[b]{2}{*}{$\mathrm{SEM}^{3}$} & \multirow[b]{2}{*}{$P$-value } \\
\hline & $\mathrm{HAD}$ & HDD & & \\
\hline $\mathrm{N}$ intake ${ }^{4} \mathrm{~g} / \mathrm{d}$ & 734 & 683 & 22.5 & 0.13 \\
\hline Urine output, L/d & 19.2 & 17.0 & 1.23 & 0.22 \\
\hline Fecal DM output, $\mathrm{kg} / \mathrm{d}$ & 9.55 & 9.29 & 0.33 & 0.58 \\
\hline \multicolumn{5}{|l|}{$\mathrm{N}$ secretion and excretion, $\mathrm{g} / \mathrm{d}$} \\
\hline Milk true protein $\mathrm{N}^{5}$ & 194 & 171 & 8.57 & 0.07 \\
\hline Urinary $\mathrm{N}^{*}$ & 192 & 147 & 8.66 & $<0.01$ \\
\hline Urinary urea-N & 121 & 85.3 & 4.22 & $<0.01$ \\
\hline Urinary urea- $\mathrm{N} \div$ total urinary $\mathrm{N}, \%$ & 64.3 & 58.6 & 2.97 & 0.19 \\
\hline Fecal N & 272 & 293 & 10.7 & 0.17 \\
\hline Total excreta $\mathrm{N}$ & 464 & 440 & 15.2 & 0.29 \\
\hline Total $\mathrm{N}$ in excreta and milk & 657 & 611 & 22.9 & 0.17 \\
\hline \multicolumn{5}{|l|}{ As proportion of $\mathrm{N}$ intake, $\%$} \\
\hline Milk true protein $\mathrm{N}$ & 26.6 & 25.1 & 0.62 & 0.12 \\
\hline Urine $\mathrm{N}$ & 26.2 & 21.7 & 1.07 & 0.01 \\
\hline Fecal N & 37.0 & 42.9 & 0.87 & $<0.01$ \\
\hline Total excreta $\mathrm{N}$ & 63.1 & 64.6 & 1.21 & 0.40 \\
\hline Total $\mathrm{N}$ in excreta and milk & 89.5 & 89.5 & 1.50 & 0.99 \\
\hline \multicolumn{5}{|l|}{ Urinary PD excretion, $\mathrm{mmol} / \mathrm{d}$} \\
\hline Uric acid & 53.8 & 45.4 & 3.46 & 0.10 \\
\hline Allantoin & 481 & 459 & 23.8 & 0.52 \\
\hline Total PD & 535 & 504 & 26.1 & 0.42 \\
\hline
\end{tabular}

${ }^{1}$ Data in this table (N intake, milk true protein, and urinary and fecal $\mathrm{N}$ ) are for wk 9 only when urine and fecal samples were collected.

${ }^{2} \mathrm{HAD}=$ diet supplying digestible His at $2.5 \%$ of $\mathrm{MP}$; HDD = diet supplying digestible His at $1.9 \%$ of MP.

${ }^{3}$ Largest SEM published in table; $\mathrm{n}=24$ ( $\mathrm{n}$ represents number of observations used in the statistical analysis).

${ }^{4} \mathrm{~N}$ intake data include $\mathrm{N}$ from supplemental rumen-protected Met (RPMet) and rumen-protected Lys (RPLys).

${ }^{5}$ Milk true protein $\div 6.38$. 
Table 7. Effects of dietary His supply on blood plasma metabolites and hormones in dairy cows

\begin{tabular}{|c|c|c|c|c|}
\hline \multirow[b]{2}{*}{ Item } & \multicolumn{2}{|c|}{$\operatorname{Diet}^{1,2}$} & \multirow[b]{2}{*}{$\mathrm{SEM}^{3}$} & \multirow[b]{2}{*}{$P$-value } \\
\hline & HAD & HDD & & \\
\hline Urea-N, mg/dL & 15.1 & 12.6 & 0.59 & 0.01 \\
\hline Creatinine, $\mathrm{mg} / \mathrm{dL}$ & 1.28 & 1.26 & 0.038 & 0.68 \\
\hline Glucose, $\mathrm{mg} / \mathrm{dL}$ & 54.9 & 52.8 & 1.28 & 0.26 \\
\hline NEFA, $\mu \mathrm{Eq} / \mathrm{L}$ & 89.8 & 93.0 & 7.11 & 0.75 \\
\hline Leptin, $\mathrm{ng} / \mathrm{mL}$ & 4.30 & 3.49 & 0.295 & 0.06 \\
\hline Insulin, $\mu \mathrm{IU} / \mathrm{mL}$ & 21.0 & 17.7 & 1.57 & 0.16 \\
\hline
\end{tabular}

ECM yield tended to increase $(+2 \mathrm{~kg} / \mathrm{d})$ because of the numerical increases in milk, fat, and protein yields, following the increase in DMI.

Milk fat concentration was not affected by HDD. Others studies using His-deficient infusions (Kim et al., 1999; Cant et al., 2001) or feeding a low-His feed
(FM; Yeo et al., 2003; Stahel et al., 2014) reported an increase in milk fat concentration (and no change in milk fat yield) because of a concurrent decrease in milk yield. Feeding a His-deficient protein (FM) had no effect on milk fat concentration when milk yield was also not affected (Harris et al., 1992; Moss et al., 1995),

Table 8. Effects of dietary His supply on plasma AA and carnosine concentrations $(\mu M)$ in dairy cows

\begin{tabular}{|c|c|c|c|c|}
\hline \multirow[b]{2}{*}{ Item } & \multicolumn{2}{|c|}{$\operatorname{Diet}^{1,2}$} & \multirow[b]{2}{*}{$\mathrm{SEM}^{3}$} & \multirow[b]{2}{*}{$P$-value } \\
\hline & HAD & HDD & & \\
\hline $\operatorname{Arg}$ & 104 & 104 & 5.85 & 0.98 \\
\hline His & 90.9 & 37.3 & 4.49 & $<0.01$ \\
\hline Ile & 141 & 167 & 9.54 & 0.07 \\
\hline Leu & 328 & 262 & 16.8 & 0.01 \\
\hline Lys & 113 & 92.4 & 5.50 & 0.01 \\
\hline Met & 29.9 & 33.1 & 1.78 & 0.20 \\
\hline Phe & 79.1 & 73.3 & 3.00 & 0.18 \\
\hline Thr & 118 & 124 & 9.42 & 0.67 \\
\hline Val & 440 & 358 & 23.1 & 0.02 \\
\hline $\mathrm{EAA}^{4}$ & 1,444 & 1,250 & 70.3 & 0.06 \\
\hline Ala & 352 & 342 & 19.2 & 0.71 \\
\hline Asn & 61.3 & 54.5 & 3.34 & 0.16 \\
\hline Asp & 7.50 & 6.95 & 0.480 & 0.41 \\
\hline Citrulline & 108 & 105 & 5.84 & 0.70 \\
\hline Gln & 372 & 365 & 15.5 & 0.74 \\
\hline Glu & 59.4 & 56.7 & 3.30 & 0.56 \\
\hline Gly & 370 & 397 & 22.1 & 0.38 \\
\hline Orn & 59.4 & 53.0 & 2.74 & 0.11 \\
\hline Pro & 128 & 139 & 7.53 & 0.32 \\
\hline Ser & 109 & 123 & 8.37 & 0.25 \\
\hline Tau & 41.2 & 53.8 & 3.13 & 0.01 \\
\hline Tyr & 71.9 & 75.0 & 3.70 & 0.56 \\
\hline $\mathrm{NEAA}^{5}$ & 1.739 & 1,772 & 84.67 & 0.78 \\
\hline Carnosine $^{6}$ & 16.0 & 11.0 & 0.98 & $<0.01$ \\
\hline $1-\mathrm{MH}^{7}$ & 15.4 & 15.8 & 0.91 & 0.71 \\
\hline Phosphoserine & 4.62 & 5.11 & 0.22 & 0.14 \\
\hline Phosphoethanolamine & 21.3 & 21.8 & 1.07 & 0.73 \\
\hline$\alpha$-Aminobutyric acid & 21.8 & 19.0 & 2.37 & 0.40 \\
\hline
\end{tabular}

${ }^{1} \mathrm{HAD}=$ diet supplying digestible His at $2.5 \%$ of MP; HDD = diet supplying digestible His at $1.9 \%$ of MP

${ }^{2}$ Covariate-adjusted LSM. Data in this table are for wk 4 and 9 when blood samples were collected.

${ }^{3}$ Largest SEM published in table, $\mathrm{n}=23$ (n represents number of observations used in the statistical analysis). ${ }^{4}$ Sum of all EAA (without Trp)

${ }^{5}$ Sum of all NEAA (Ala, Asn, Asp, Citrulline, Gln, Glu, Gly, Orn, Pro, Ser, Tau, and Tyr were considered as NEAA).

${ }^{6}$ Dipeptide ( $\beta$-alanyl-L-His).

${ }^{7} 1$-Methylhistidine. 
whereas Tomlinson et al. (1994) reported a decrease in milk fat concentration.

In the current study, BW gain was not influenced by diet. However, histidine deficiency and lower DMI, and consequently, the lower supply of total $\mathrm{NE}_{\mathrm{L}}$ and dEAA with HDD may have impaired not only yields of milk and milk components but also body fat and protein synthesis (see decline in muscle free His concentration). A negative effect of MP and EAA deficiencies on BW gain was observed by Giallongo et al. (2015). Fraser et al. (1991) reported a decrease in retained $\mathrm{N}$ in lactating dairy cows, when His or Met, Lys, and Phe were individually removed from the EAA infusion mixture. Depressed BW gain has also been reported in rats fed diets deficient in His alone versus His-adequate diets (Tamaki et al., 1977; Clemens et al., 1984).

Milk FA composition was generally not influenced by diet in the present study. The slight trend for lower 8:0 and higher 16:0 with HDD compared with HAD may be due to changes in de novo synthesis of FA in the mammary gland (Bauman and Griinari, 2003), but not from higher supply of dietary 16:0 with HDD (i.e., FM contains less 16:0 than Megalac; Cotanch et al., 2007). Tomlinson et al. (1994) observed a decrease in 8:0 (10:0, 14:0, and 16:1), with no changes in 16:0, when FM substituted BM in the diet of dairy cows. Milk 14:0 iso, an odd- and branched-chain fatty acid present in

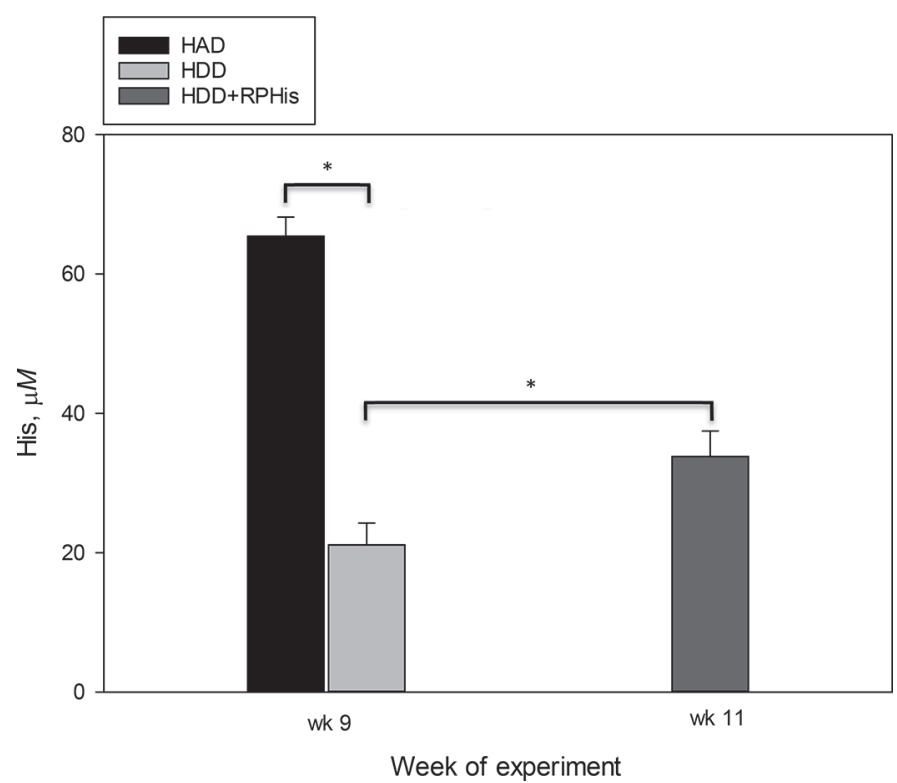

Figure 2. Plasma His concentrations (mean \pm SEM) during wk 9 of the experiment in dairy cows fed a diet supplying digestible His (dHis) at $2.5 \%$ of MP (HAD) or a diet supplying dHis at $1.9 \%$ of MP (HDD). In wk 11, the HDD diet was supplemented with rumen-protected (RP) His (see Materials and Methods). Significant differences between HAD and HDD and between HDD and HDD+RPHis are denoted as $* P \leq 0.01$. high concentrations in some rumen cellulolytic bacteria (Fievez et al., 2012), was decreased with HDD versus HAD. This and the above-mentioned minor changes in milk FA in the present study may also be a result of individual animal variability.

Apparent total-tract digestibility of $\mathrm{CP}$ and $\mathrm{NDF}$ was decreased by about 3 to $6 \%$-units in cows fed HDD compared with HAD. The decline in $\mathrm{CP}$ digestibility is in agreement with the lower RUP digestibility of FM versus BM. Similar lower CP digestibilities were observed when FM replaced BM in dairy cow (Waltz et al., 1989) and sheep (Blasi et al., 1991) diets. The observed lower NDF digestibility with HDD can be mainly attributed to the high NDF content (most likely of NDICP nature; Cotanch et al., 2007) of FM relative to $\mathrm{BM}$ (29.4 vs. $0.4 \%$ of $\mathrm{DM}$ ). In addition, a negative effect of the decreased supply of specific AA (i.e., Lys, Leu, Phe, and Val) in the rumen with HDD versus HAD on microbial growth and fiber digestibility (Mir et al., 1986; Atasoglu et al., 2004; see discussions in Giallongo et al., 2015) cannot be excluded. No differences in rumen NDF digestibility were observed by Waltz et al. (1989) when substituting FM with BM in the diet of dairy cows.

The HDD decreased milk and plasma urea-N concentrations, and urinary $\mathrm{N}$ and urea- $\mathrm{N}$ excretions. These effects can be attributed to the observed lower digest-

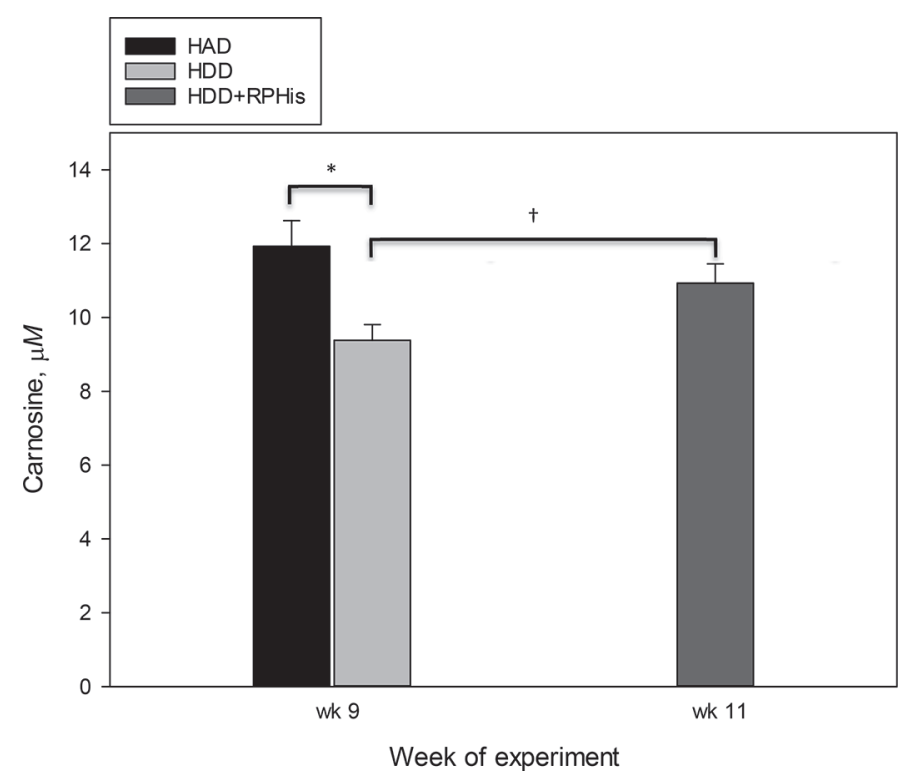

Figure 3. Plasma carnosine concentrations (mean \pm SEM) during wk 9 of the experiment in dairy cows fed a diet supplying digestible His (dHis) at $2.5 \%$ of MP (HAD) or a diet supplying dHis at $1.9 \%$ of MP (HDD). In wk 11, the HDD diet was supplemented with rumenprotected (RP) His (see Materials and Methods). Significant differences between HAD and HDD and between HDD and HDD+RPHis are denoted as $* P \leq 0.01, \dagger P \leq 0.10$. 
ibility of CP, and estimated (NRC, 2001) lower protein fractions (MP, RDP, and RUP) balance with HDD than HAD (Patton et al., 2014; Giallongo et al., 2016). Because of these effects, the proportion of urinary $\mathrm{N}$ was decreased and that of fecal $\mathrm{N}$ was increased by HDD versus HAD. Similar outcomes have been reported with a wider range of protein fractions balance in dairy cows (Groff and Wu, 2005).

Cows fed HDD had numerically lower milk N efficiency than cows fed HAD. In the present experiment, both diets provided adequate amount of dMet and
dLys (as described above), and the dHis deficiency with HDD may have impaired milk protein synthesis in the mammary gland, contributing to lower milk $\mathrm{N}$ efficiency (Doepel et al., 2004). Indeed, balancing EAA profile of diets with His (Huhtanen et al., 2002) and a mixture of EAA (i.e., Lys, Met, His, and Leu; Haque et al., 2012) has been shown to increase MPY and the efficiency of $\mathrm{N}$ utilization.

Plasma creatinine concentrations were not different between HAD and HDD, in agreement with the similar BW, BCS, and positive BW change of the cows (Pires

Table 9. Effects of dietary His supply on muscle free AA and dipeptide concentrations $(\mu \mathrm{g} / \mathrm{g})$ in dairy cows

\begin{tabular}{|c|c|c|c|c|}
\hline \multirow[b]{2}{*}{ Item } & \multicolumn{2}{|c|}{ Diet $^{1}$} & \multirow[b]{2}{*}{$\mathrm{SEM}^{2}$} & \multirow[b]{2}{*}{$P$-value } \\
\hline & HAD & HDD & & \\
\hline$\overline{\operatorname{Arg}}$ & 4.46 & 6.58 & 1.187 & 0.22 \\
\hline His & 7.80 & 3.65 & 0.667 & $<0.01$ \\
\hline Ile & 9.93 & 8.34 & 0.835 & 0.19 \\
\hline Leu & 21.3 & 14.9 & 1.74 & 0.02 \\
\hline Lys & 13.0 & 12.0 & 1.422 & 0.64 \\
\hline Met & 4.50 & 4.68 & 0.673 & 0.84 \\
\hline Phe & 9.05 & 7.89 & 0.842 & 0.34 \\
\hline Thr & 10.5 & 14.3 & 2.37 & 0.27 \\
\hline Val & 22.0 & 13.5 & 1.783 & $<0.01$ \\
\hline $\mathrm{EAA}^{3}$ & 102 & 86.0 & 9.492 & 0.23 \\
\hline Ala & 86.0 & 93.6 & 11.64 & 0.65 \\
\hline Asn & 1.59 & 1.99 & 0.901 & 0.76 \\
\hline Asp & 5.88 & 2.05 & 1.822 & 0.15 \\
\hline Citrulline & 7.64 & 6.62 & 0.658 & 0.29 \\
\hline Gln & 265 & 279 & 44.3 & 0.82 \\
\hline Glu & 81.7 & 103 & 16.37 & 0.37 \\
\hline Gly & 47.2 & 82.8 & 14.68 & 0.10 \\
\hline Orn & 5.40 & 6.37 & 0.775 & 0.38 \\
\hline Pro & 14.5 & 17.8 & 2.71 & 0.40 \\
\hline Ser & 17.2 & 24.5 & 4.38 & 0.25 \\
\hline $\mathrm{Tau}$ & 84.6 & 83.8 & 11.97 & 0.96 \\
\hline Tyr & 9.09 & 9.26 & 1.082 & 0.91 \\
\hline $\mathrm{NEAA}^{4}$ & 625 & 711 & 97.5 & 0.54 \\
\hline$\beta$-Alanine & 8.03 & 15.7 & 3.180 & 0.10 \\
\hline Carnosine $^{5}$ & 1,872 & 1,620 & 209.5 & 0.40 \\
\hline Anserine $^{6}$ & 294 & 262 & 38.1 & 0.56 \\
\hline $1-\mathrm{MH}^{7}$ & 1.25 & 1.41 & 0.269 & 0.69 \\
\hline $3-\mathrm{MH}^{8}$ & 0.54 & 0.49 & 0.124 & 0.79 \\
\hline Phosphoserine & 9.00 & 8.48 & 0.627 & 0.56 \\
\hline Hydroxyproline & 2.34 & 2.56 & 0.702 & 0.83 \\
\hline Sarcosine & 9.15 & 10.0 & 1.350 & 0.64 \\
\hline Homocystine & 0.12 & 0.15 & 0.051 & 0.73 \\
\hline$\alpha$-Amino-adipic acid & 3.46 & 3.08 & 0.548 & 0.63 \\
\hline$\alpha$-Amino-n-butyric acid & 1.32 & 1.20 & 0.371 & 0.82 \\
\hline$\beta$-Amino-isobutyric acid & 0.13 & 0.19 & 0.075 & 0.56 \\
\hline$\gamma$-Amino-butyric acid & 1.32 & 1.59 & 0.351 & 0.59 \\
\hline Urea & 239 & 210 & 21.97 & 0.37 \\
\hline
\end{tabular}

${ }^{1} \mathrm{HAD}=$ diet supplying digestible His at $2.5 \%$ of MP; HDD = diet supplying digestible His at $1.9 \%$ of MP.

${ }^{2}$ Largest SEM published in table, $\mathrm{n}=23$ to 24 (n represents number of observations used in the statistical analysis). Data in this table are for wk 10 only when muscle biopsies were collected.

${ }^{3}$ Sum of all EAA (without Trp).

${ }^{4}$ Sum of all NEAA (Ala, Asn, Asp, Citrulline, Gln, Glu, Gly, Orn, Pro, Ser, Tau, and Tyr were considered as NEAA).

${ }^{5}$ Dipeptide ( $\beta$-alanyl-L-His).

${ }^{6}$ Dipeptide ( $\beta$-alanyl-1- $N$-methyl-L-His).

${ }^{7} 1$-Methylhistidine.

${ }^{8}$ 3-Methylhistidine. 


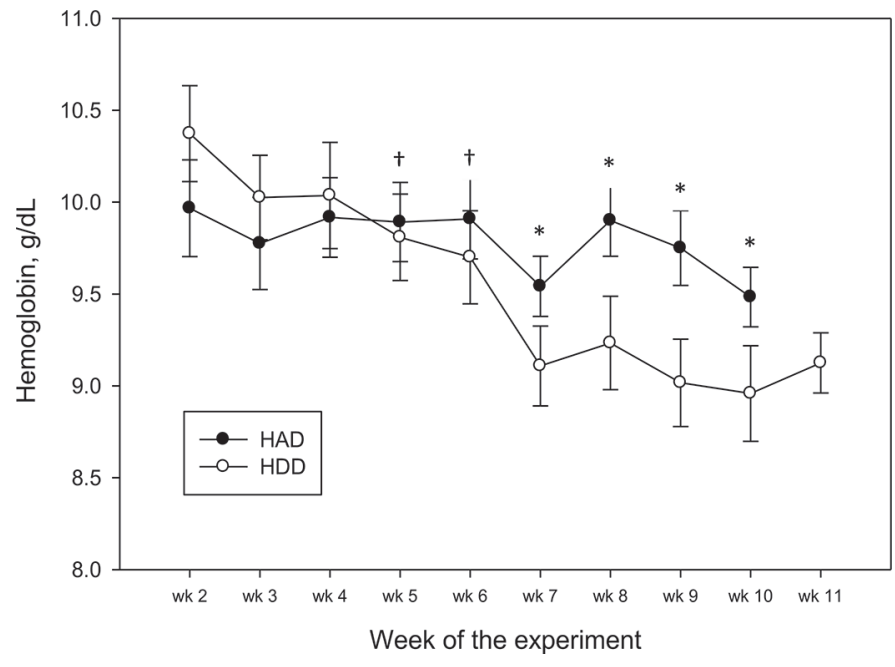

Figure 4. Blood hemoglobin concentrations (mean \pm SEM) from wk 2 (covariate period) to wk 11 of the experiment in dairy cows fed a diet supplying digestible His (dHis) at $2.5 \%$ of MP (HAD) or a diet supplying dHis at $1.9 \%$ of MP (HDD). In wk 11, the HDD diet was supplemented with rumen-protected (RP) His (see Materials and Methods). Significant differences between HAD and HDD are denoted as $* P \leq 0.04, \dagger P \leq 0.10$.

et al., 2013; Giallongo et al., 2016). Plasma glucose concentration was not affected by diet, most likely because of the same starch content of the diets and similar starch intake between HAD and HDD cows (Giallongo et al., 2016). In the current study, plasma NEFA concentration did not differ between the 2 diets. Cows were in mid-lactation and these results are likely due to lack of difference in body fat mobilization, and are in line with the observed positive energy balance and BW gain of the cows. Similar findings were also reported by others (Reynolds et al., 2003; Stahel et al., 2014).

Plasma leptin concentration tended to be lower in cows with the lower DMI (i.e., HDD vs. HAD). This result is consistent with previous studies that showed a positive association of feed intake, feeding level, or both, with plasma leptin in sheep (Blache et al., 2000), dairy cows (Delavaud et al., 2002), and beef steers and heifers (Foote et al., 2016). Although the exact mechanism is not clear in dairy cows, lower feed intake could reduce insulin-stimulated leptin mRNA expression and leptin synthesis in white adipose tissue (Amstalden et al., 2000; Block et al., 2003; Leury et al., 2003). Plasma leptin is also known to be positively correlated with body fatness in sheep (Delavaud et al., 2000), dairy cows (Kokkonen et al., 2005), and beef steers and heifers (Foote et al., 2016). Body fat, however, was not evaluated in the current experiment.

The decline in plasma EAA observed for HDD compared with $\mathrm{HAD}$ is in line with the decreased supply of dEAA estimated using NRC (2001). In agreement with these results, Pacheco et al. (2012) showed that NRC (2001) is accurate in predicting flow of dEAA and a meta-analysis by Patton et al. (2015) reported a linear relation between duodenal flow of EAA and plasma EAA concentrations in dairy cows.

The observed lower plasma His and Car concentrations during wk 9 reflected the designed His deficiency with HDD compared with HAD (and HDD+RPHis). These results agree with the decreases in plasma His and Car reported by Ouellet et al. (2014) in dairy cows abomasally infused with decreasing amounts of His (from 2.5 to $1.5 \%$ of MP) in short-term 7-d periods.

Blood $\mathrm{Hb}$ and muscle His-dipeptides (i.e., Car and Ans) are the main endogenous reserves that can supply His to the cow during periods of deficiency, which may complicate establishing His requirements (Lapierre et al., 2008). The provision of His from muscle Car and blood $\mathrm{Hb}$ have been suggested to help sustain MPY and plasma His concentrations (masking a dietary deficiency) in short-term studies (Lapierre et al., 2008; Lee et al., 2012). However, sharp decreases in plasma His and MPY with dietary His supply below $2.2 \%$ and $1.8 \%$ of MP (Ouellet et al., 2014) and 2.0\% of MP (Lapierre et al., 2014), respectively, were also observed in shortterm 7- to 14-d periods. Thus, it is not clear to what extent these endogenous pools can provide His, and whether they can help to alleviate a dietary deficiency.

In the current study, the $13.6 \%$ decline in blood $\mathrm{Hb}$ in cows fed HDD was estimated (according to Giallongo et al., 2016) to supply about 39.0 g (i.e., about $0.7 \mathrm{~g} / \mathrm{d}$ ) of His over the 8-wk experimental period. The decrease in blood $\mathrm{Hb}$ during periods of His deficiency has been mainly attributed to a reduction in $\mathrm{Hb}$ synthesis (Clemens et al., 1984; Kriengsinyos et al., 2002). Relative to the plasma His concentration of HDD at wk 2 , plasma His of HDD cows was not different during wk 9 (data not shown), indicating that the supply of His from $\mathrm{Hb}$, likely together with other mechanisms such as decreased catabolism and urinary excretion of His (Kopple and Swendseid, 1981; Clemens et al., 1984), was likely able to sustain plasma His concentrations during this period. Similarly, reductions in plasma His and blood $\mathrm{Hb}$ (i.e., a supply of about $0.4 \mathrm{~g} / \mathrm{d}$ of His from $\mathrm{Hb}$ ) were observed in our previous study in cows fed MP-deficient diets providing dHis at $2.1 \%$ versus $2.4 \%$ of MP (Giallongo et al., 2016). Negative effects of dietary His deficiency on blood His and Hb concentrations have also been reported in various nonruminant species including adult humans (Cho et al., 1984; Kriengsinyos et al., 2002), rats (Clemens et al., 1984), cockerels (Amend et al., 1979), and dogs (Cianciaruso et al., 1981).

Lapierre et al. (2014) reported quadratic trends for lower blood $\mathrm{Hb}$ and muscle Car and Ans at dHis supply 
below and above $2.3 \%$ of MP (i.e., 1.60, 1.95, and $2.65 \%$ of MP) in short-term 14-d periods. In the present study, the deficiency of His with HDD was sufficient to trigger a decrease in plasma His, muscle free His, and blood $\mathrm{Hb}$, but not in muscle Car and Ans. These results suggest that, in agreement with previous observations in rats (Clemens et al., 1984), the maintenance of plasma His, muscle free His, and blood $\mathrm{Hb}$ have a lower metabolic priority than muscle Car and Ans. In our previous study, muscle Car and Ans were also not affected by a diet supplying dHis at $2.0 \%$ versus $2.3 \%$ of MP (Giallongo et al., 2015). In this experiment, the marked decline in muscle free His together with the trend for higher $\beta$-alanine in HDD cows is consistent with previous findings in broilers (Haug et al., 2008) and adult humans (Kopple and Swendseid, 1975) fed His-deficient diets, suggesting a release of His from muscle and a likely impaired synthesis or degradation (or both) of muscle Car and Ans due to His deficiency (Tamaki et al., 1977; Clemens et al., 1984). The supply of His from muscle free His with HDD was estimated (based on the analyzed muscle free His concentration and assuming a muscle mass of $28.5 \%$ of BW; Jurie et al., 2007) to be negligible (i.e., about $0.8 \mathrm{~g}$ over the $8 \mathrm{wk}$ ). Feeding nonruminant animals diets more deficient in His, compared with the current study, has been shown to reduce muscle free His and also Car in broilers (Haug et al., 2008), rats (Tamaki et al., 1977; Clemens et al., 1984), cockerels (Amend et al., 1979), and dogs (Cianciaruso et al., 1981), but not muscle Ans in rats (Tamaki et al., 1977; Clemens et al., 1984), and cockerels (Amend et al., 1979). Based on the analyzed muscle Car and Ans concentrations, these 2 His-dipeptides were estimated (as described above) to store about $270 \mathrm{~g}$ of His, whereas blood $\mathrm{Hb}$ was calculated (according to Giallongo et al., 2016) to contain about $380 \mathrm{~g}$ of His. On the basis of the calculated dHis deficiency with $\operatorname{HDD}(-6 \mathrm{~g} / \mathrm{d})$, muscle Car and blood $\mathrm{Hb}$ (assuming depletion of up to $85 \%$ and $25 \%$, respectively; Amend et al., 1979) may, in theory, provide enough His for approximately 7 wk. Nevertheless, based on the observations in this study, blood $\mathrm{Hb}$ seems to play a greater role than muscle Car in the supply of His during periods of deficiency, but not to the extent to alleviate the negative effects of the HDD on lactational performance of dairy cows.

\section{CONCLUSIONS}

In this study, feeding a His-deficient diet supplying adequate MP, dMet, and dLys decreased DMI, yields of milk, protein, and ECM in dairy cows. Apparent totaltract digestibility of $\mathrm{DM}, \mathrm{OM}, \mathrm{CP}$, and NDF, milk and plasma urea- $\mathrm{N}$ and urinary $\mathrm{N}$ excretion were decreased by HDD compared with HAD. Cows fed HDD had lower plasma concentrations of His, Car, and leptin. Muscle free His and blood $\mathrm{Hb}$ concentrations were decreased by HDD compared with HAD, indicating an endogenous supply of His triggered by dietary deficiency. Supplementation of HDD with RPHis during wk 11 increased DMI and plasma His, and tended to increase ECM yield and plasma Car concentrations, compared with HDD. Overall, feeding a diet providing on average 1.9\% dHis of MP had negative effects on DMI and lactational performance of dairy cows. These results confirm our previous data that low dietary His supply can impair DMI, yields of milk and milk protein, and blood $\mathrm{Hb}$ in dairy cows. Supplementation of such diets with RPHis has the potential to reverse these effects.

\section{ACKNOWLEDGMENTS}

The authors thank Evonik Nutrition \& Care GmbH (Hanau, Germany) for supplying Mepron and for AA analyses of the feed and plasma samples, Ajinomoto Co. Inc. (Tokyo, Japan) for supplying AjiPro-L and the experimental RPHis product, and Darling Ingredients Inc. (Irving, TX) for supplying hydrolyzed feather meal at a reduced price for the experiment. The authors also thank Jacob Werner (Animal Resource Program, The Pennsylvania State University, University Park) for performing the muscle biopsies, Charles H. Lang's laboratory (Department of Cellular and Molecular Physiology, Penn State College of Medicine, Hershey, PA) for preparing muscle homogenates, Kevin Harvatine's laboratory (The Pennsylvania State University, University Park) for assisting with the milk FA analyses, and the staff of the Department of Animal Science Dairy Center (The Pennsylvania State University, University Park) for their conscientious care of the experimental cows.

\section{REFERENCES}

Amend, J. F., D. H. Strumeyer, and H. Fisher. 1979. Effect of dietary histidine on tissue concentrations of histidine-containing dipeptides in adult cockerels. J. Nutr. 109:1779-1786.

Amstalden, M., M. R. Garcia, S. W. Williams, R. L. Stanko, S. E. Nizielski, C. D. Morrison, D. H. Keisler, and G. L. Williams. 2000. Leptin gene expression, circulating leptin, and luteinizing hormone pulsatility are acutely responsive to short-term fasting in prepubertal heifers: Relationships to circulating insulin and insulin-like growth factor I(1). Biol. Reprod. 63:127-133.

AOAC International. 1995. Official Methods of Analysis. 16th ed. AOAC Int., Arlington, VA.

AOAC International. 2012. Official Methods of Analysis. 19th ed. AOAC International, Arlington, VA.

Atasoglu, C., A. Y. Guliye, and R. J. Wallace. 2004. Use of stable isotopes to measure de novo synthesis and turnover of amino acid-C and $-\mathrm{N}$ in mixed micro-organisms from the sheep rumen in vitro. Br. J. Nutr. 91:253-262.

Bauman, D. E., and J. M. Griinari. 2003. Nutritional regulation of milk fat synthesis. Annu. Rev. Nutr. 23:203-227. 
Blache, D., R. L. Tellam, L. M. Chagas, M. A. Blackberry, P. E. Vercoe, and G. B. Martin. 2000. Level of nutrition affects leptin concentrations in plasma and cerebrospinal fluid in sheep. J. Endocrinol. 165:625-637.

Blasi, D. A., T. J. Klopfenstein, and J. S. Drouillard. 1991. Hydrolysis time as a factor affecting the nutritive value of feather meal and feather meal-blood meal combinations for growing calves. J. Anim. Sci. 69:1272-1278.

Block, S. S., R. P. Rhoads, D. E. Bauman, R. A. Ehrhardt, M. A. McGuire, B. A. Crooker, J. M. Griinari, T. R. Mackle, W. J. Weber, M. E. Van Amburgh, and Y. R. Boisclair. 2003. Demonstration of a role for insulin in the regulation of leptin in lactating dairy cows. J. Dairy Sci. 86:3508-3515.

Cant, J. P., D. R. Trout, F. Qiao, and B. W. McBride. 2001. Milk composition responses to unilateral arterial infusion of complete and histidine-lacking amino acid mixtures to the mammary glands of cows. J. Dairy Sci. 84:1192-1200.

Cho, E. S., H. L. Anderson, R. L. Wixom, K. C. Hanson, and G. F. Krause. 1984. Long-term effects of low histidine intake on men. J. Nutr. 114:369-384.

Cianciaruso, B., M. R. Jones, and J. D. Kopple. 1981. Histidine, an essential amino acid for adult dogs. J. Nutr. 111:1074-1084.

Clemens, R. A., J. D. Kopple, and M. E. Swendseid. 1984. Metabolic effects of histidine deficient diets fed to growing rats by gastric tube. J. Nutr. 114:2138-2146.

Cotanch, K. W., R. J. Grant, H. M. Dann, and J. W. Darrah. 2007. Analysis of nutrient composition of feather meal and feather meal with blood. www.poultryegg.org/PPFC/docs/ProjectR54.pdf. (Accessed May 16, 2007.)

Delavaud, C., F. Bocquier, Y. Chilliard, D. H. Keisler, A. Gertler, and G. Kann. 2000. Plasma leptin determination in ruminants: Effect of nutritional status and body fatness on plasma leptin concentration assessed by a specific RIA in sheep. J. Endocrinol. 165:519-526.

Delavaud, C., A. Ferlay, Y. Faulconnier, F. Bocquier, G. Kann, and Y. Chilliard. 2002. Plasma leptin concentration in adult cattle: Effects of breed, adiposity, feeding level, and meal intake. J. Anim. Sci. 80:1317-1328.

Deyl, Z., J. Hyanek, and M. Horakova. 1986. Profiling of amino acids in body fluids and tissues by means of liquid chromatography. J. Chromatogr. 379:177-250.

Doelman, J., R. V. Curtis, M. Carson, J. J. M. Kim, J. A. Metcalf, and J. P. Cant. 2015. Essential amino acid infusions stimulate mammary expression of eukaryotic initiation factor $2 \mathrm{~B} \varepsilon$ but milk protein yield is not increased during an imbalance. J. Dairy Sci. 98:4499-4508.

Doepel, L., I. I. Hewage, and H. Lapierre. 2016. Milk protein yield and mammary metabolism are affected by phenylalanine deficiency but not by threonine or tryptophan deficiency. J. Dairy Sci. 99:3144-3156.

Doepel, L., D. Pacheco, J. J. Kennelly, M. D. Hanigan, I. F. Lopez, and H. Lapierre. 2004. Milk protein synthesis as a function of amino acid supply. J. Dairy Sci. 87:1279-1297.

Edmonson, A. J., I. J. Lean, L. D. Weaver, T. Farver, and G. Webster. 1989. A body condition scoring chart for Holstein dairy cows. J. Dairy Sci. 72:68-78.

European Commission. 2009. 2009/150/EC Commission regulation laying down the methods of sampling and analysis for the official control of feed. Off. J. L54:1-130.

Fekkes, D. 1996. State-of-the-art of high-performance liquid chromatographic analysis of amino acids in physiological samples. J. Chromatogr. B Biomed. Appl. 682:3-22.

Fievez, V., E. Colman, J. M. Castro-Montoya, I. Stefanov, and B. Vlaeminck. 2012. Milk odd- and branched-chain fatty acids as biomarkers of rumen function-An update. Anim. Feed Sci. Technol. 172:51-65.

Foote, A. P., R. G. Tait, D. H. Keisler, K. E. Hales, and H. C. Freetly. 2016. Leptin concentrations in finishing beef steers and heifers and their association with dry matter intake, average daily gain, feed efficiency, and body composition. Domest. Anim. Endocrinol. 55:136-141.
Fraser, D. L., E. R. Ørskov, F. G. Whitelaw, and M. F. Franklin. 1991. Limiting amino acids in dairy cows given casein as the sole source of protein. Livest. Prod. Sci. 28:235-252.

Giallongo, F., M. T. Harper, J. Oh, J. C. Lopes, H. Lapierre, R. A. Patton, C. Parys, I. Shinzato, and A. N. Hristov. 2016. Effects of rumen-protected methionine, lysine, and histidine on lactation performance of dairy cows. J. Dairy Sci. 99:4437-4452.

Giallongo, F., A. N. Hristov, J. Oh, T. Frederick, H. Weeks, J. Werner, H. Lapierre, R. A. Patton, A. Gehman, and C. Parys. 2015. Effects of slow-release urea and rumen-protected methionine and histidine on performance of dairy cows. J. Dairy Sci. 98:3292-3308.

Groff, E. B., and Z. Wu. 2005. Milk production and nitrogen excretion of dairy cows fed different amounts of protein and varying proportions of alfalfa and corn silage. J. Dairy Sci. 88:3619-3632.

Hall, M. B. 2009. Analysis of starch, including maltooligosaccharides, in animal feeds: A comparison of methods and a recommended method for AOAC collaborative study. J. AOAC Int. 92:42-49.

Haque, M. N., H. Rulquin, A. Andrade, P. Faverdin, J. L. Peyraud, and S. Lemosquet. 2012. Milk protein synthesis in response to the provision of an "ideal" amino acid profile at 2 levels of metabolizable protein supply in dairy cows. J. Dairy Sci. 95:5876-5887.

Haque, M. N., H. Rulquin, and S. Lemosquet. 2013. Milk protein responses in dairy cows to changes in postruminal supplies of arginine, isoleucine, and valine. J. Dairy Sci. 96:420-430.

Harris, B., D. E. Dorminey, W. A. Smith, H. H. Van Horn, and C. J. Wilcox. 1992. Effects of feather meal at two protein concentrations and yeast culture on production parameters in lactating dairy cows. J. Dairy Sci. 75:3524-3530.

Haug, A., R. Rødbotten, L. T. Mydland, and O. A. Christophersen. 2008. Increased broiler muscle carnosine and anserine following histidine supplementation of commercial broiler feed concentrate. Acta Agric. Scand. A Anim. Sci. 58:71-77.

Hristov, A. N., C. Lee, T. Cassidy, M. Long, B. Corl, and R. Forster. 2011. Effects of lauric and myristic acids on ruminal fermentation, production, and milk fatty acid composition in lactating dairy cows. J. Dairy Sci. 94:382-395.

Huhtanen, P., A. Vanhatalo, and T. Varvikko. 2002. Effects of abomasal infusions of histidine, glucose, and leucine on milk production and plasma metabolites of dairy cows fed grass silage diets. J. Dairy Sci. 85:204-216.

Jurie, C., B. Picard, J.-F. Hocquette, E. Dransfield, D. Micol, and A. Listrat. 2007. Muscle and meat quality characteristics of Holstein and Salers cull cows. Meat Sci. 77:459-466.

Kim, C.-H., J.-J. Choung, and D. G. Chamberlain. 1999. Determination of the first-limiting amino acid for milk production in dairy cows consuming a diet of grass silage and a cereal-based supplement containing feather meal. J. Sci. Food Agric. 79:1703-1708.

Kim, C.-H., J.-J. Choung, and D. G. Chamberlain. 2001. Estimates of the efficiency of transfer of l-histidine from blood to milk when it is the first-limiting amino acid for secretion of milk protein in the dairy cow. J. Sci. Food Agric. 81:1150-1155.

Kokkonen, T., J. Taponen, T. Anttila, L. Syrjala-Qvist, C. Delavaud, Y. Chilliard, M. Tuori, and A. T. Tesfa. 2005. Effect of body fatness and glucogenic supplement on lipid and protein mobilization and plasma leptin in dairy cows. J. Dairy Sci. 88:1127-1141.

Kopple, J. D., and M. E. Swendseid. 1975. Evidence that histidine is an essential amino acid in normal and chronically uremic man. J. Clin. Invest. 55:881-891.

Kopple, J. D., and M. E. Swendseid. 1981. Effect of histidine intake of plasma and urine histidine levels, nitrogen balance and $\mathrm{N}$ taumethylhistidine excretion in normal and chronically uremic men. J. Nutr. 111:931-942.

Korhonen, M., A. Vanhatalo, and P. Huhtanen. 2002. Evaluation of isoleucine, leucine, and valine as a second-limiting amino acid for milk production in dairy cows fed grass silage diet. J. Dairy Sci. 85:1533-1545.

Korhonen, M., A. Vanhatalo, T. Varvikko, and P. Huhtanen. 2000. Responses to graded postruminal doses of histidine in dairy cows fed grass silage diets. J. Dairy Sci. 83:2596-2608. 
Kriengsinyos, W., M. Rafii, L. J. Wykes, R. O. Ball, and P. B. Pencharz. 2002. Long-term effects of histidine depletion on whole-body protein metabolism in healthy adults. J. Nutr. 132:3340-3348.

Lang, C. H., A. Pruznak, M. Navaratnarajah, K. A. Rankine, G. Deiter, H. Magne, E. A. Offord, and D. Breuillé. 2013. Chronic $\alpha$-hydroxyisocaproic acid treatment improves muscle recovery after immobilization-induced atrophy. Am. J. Physiol. Endocrinol. Metab. 305:E416-E428.

Lapierre, H., D. R. Ouellet, L. Doepel, G. Holtrop, and G. E. Lobley. 2008. Histidine, lysine and methionine: From metabolism to balanced dairy rations. Pages 19-36 in Proc. 44th Eastern Nutrition Conference of the Animal Nutrition Association of Canada (ANAC), University of Guelph, Guelph, ON, Canada. University of Guelph, Guelph, ON, Canada.

Lapierre, H., D. R. Ouellet, and G. E. Lobley. 2014. Estimation of histidine requirement in lactating dairy cows. J. Dairy Sci. 97(Suppl. 1):757-758. (Abstr.)

Lee, C., A. N. Hristov, T. W. Cassidy, K. S. Heyler, H. Lapierre, G. A. Varga, M. J. de Veth, R. A. Patton, and C. Parys. 2012. Rumenprotected lysine, methionine, and histidine increase milk protein yield in dairy cows fed a metabolizable protein-deficient diet. J. Dairy Sci. 95:6042-6056.

Leury, B. J., L. H. Baumgard, S. S. Block, N. Segoale, R. A. Ehrhardt, R. P. Rhoads, D. E. Bauman, A. W. Bell, and Y. R. Boisclair. 2003. Effect of insulin and growth hormone on plasma leptin in periparturient dairy cows. Am. J. Physiol. Regul. Integr. Comp. Physiol. 285:R1107-R1115.

Mir, P. S., Z. Mir, and J. A. Robertson. 1986. Effect of branched chain amino acids or fatty acid supplementation on in vitro digestibility of barley straw or alfalfa hay. Can. J. Anim. Sci. 66:151-156.

Moss, B. R., J. C. Lin, J. R. Steenstra, and R. C. Smith. 1995. Effect of feather meal and blood meal supplementation on performance of dairy cattle. Prof. Anim. Sci. 11:88-94.

NRC. 2001. Nutrient Requirements of Dairy Cattle. 7th rev. ed. Natl. Acad. Sci., Washington, DC.

Ouellet, D. R., G. E. Lobley, and H. Lapierre. 2014. Histidine requirement of dairy cows determined by the indicator amino acid oxidation (AAO) technique. J. Dairy Sci. 97(Suppl. 1):757. (Abstr.)

Pacheco, D., R. A. Patton, C. Parys, and H. Lapierre. 2012. Ability of commercially available dairy ration programs to predict duodenal flows of protein and essential amino acids in dairy cows. J. Dairy Sci. 95:937-963.

Patton, R. A., A. N. Hristov, and H. Lapierre. 2014. Protein feeding and balancing for amino acid in lactating dairy cattle. Pages 599-621 in Veterinary Clinics of North America. R. J. Van Saun and R. A. Smith, ed. Elsevier, Philadelphia, PA.

Patton, R. A., A. N. Hristov, C. Parys, and H. Lapierre. 2015. Relationships between circulating plasma concentrations and duodenal flows of essential amino acids in lactating dairy cows. J. Dairy Sci. 98:4707-4734.

Pires, J. A., C. Delavaud, Y. Faulconnier, D. Pomies, and Y. Chilliard. 2013. Effects of body condition score at calving on indicators of fat and protein mobilization of periparturient Holstein-Friesian cows. J. Dairy Sci. 96:6423-6439.

Reynolds, C. K., P. C. Aikman, B. Lupoli, D. J. Humphries, and D. E. Beever. 2003. Splanchnic metabolism of dairy cows during the transition from late gestation through early lactation. J. Dairy Sci. $86: 1201-1217$.

Rico, D. E., and K. J. Harvatine. 2013. Induction of and recovery from milk fat depression occurs progressively in dairy cows switched between diets that differ in fiber and oil concentration. J. Dairy Sci. 96:6621-6630.

Robinson, P. H., W. Chalupa, C. J. Sniffen, W. E. Julien, H. Sato, T. Fujeda, T. Ueda, and H. Suzuki. 2000. Influence of abomasal infusion of high levels of lysine or methionine, or both, on ruminal fermentation, eating behavior, and performance of lactating dairy cows. J. Anim. Sci. 78:1067-1077.
Ross, D. A., M. Gutierrez-Botero, and M. E. Van Amburgh. 2013. Development of an in vitro intestinal digestibility assay for ruminant feeds. Proceedings of the Cornell Nutrition Conference for Feed Manufacturers, 190-202.

Rulquin, H., and P. M. Pisulewski. 2006. Effects of graded levels of duodenal infusions of leucine on mammary uptake and output in lactating dairy cows. J. Dairy Res. 73:328-339.

Schneider, B. H., and W. P. Flatt. 1975. The evaluation of feeds through digestibility experiments. University of Georgia Press, Athens, GA.

Schwab, C. G., P. Huhtanen, C. W. Hunt, and T. Hvelplund. 2005. Nitrogen requirements of cattle. Pages 13-70 in Nitrogen and Phosphorus Nutrition of Cattle and Environment. E. Pfeffer and A. N. Hristov, ed. CAB Int., Wallingford, UK.

Schwab, C. G., L. D. Satter, and A. B. Clay. 1976. Response of lactating dairy cows to abomasal infusion of amino acids. J. Dairy Sci. 59:1254-1270.

Sinclair, K. D., P. C. Garnsworthy, G. E. Mann, and L. A. Sinclair. 2014. Reducing dietary protein in dairy cow diets: Implications for nitrogen utilization, milk production, welfare and fertility. Animal $8: 262-274$

Sjaunja, L. O., L. Baevre, L. Junkkarinen, J. Pedersen, and J. Setälä. 1990. A Nordic proposal for an energy corrected milk (ECM) formula. Proc. 27th Session Int. Comm. Breeding Product. Milk Anim., Paris, France. Wageningen Acad. Publ., Wageningen, the Netherlands.

Socha, M. T., D. E. Putnam, B. D. Garthwaite, N. L. Whitehouse, N. A. Kierstead, C. G. Schwab, G. A. Ducharme, and J. C. Robert. 2005. Improving intestinal amino acid supply of pre- and postpartum dairy cows with rumen-protected methionine and lysine. J. Dairy Sci. 88:1113-1126.

Stahel, P., N. G. Purdie, and J. P. Cant. 2014. Use of dietary feather meal to induce histidine deficiency or imbalance in dairy cows and effects on milk composition. J. Dairy Sci. 97:439-445.

Swanepoel, N., P. H. Robinson, and L. J. Erasmus. 2016. Impacts of adding ruminally protected phenylalanine to rations containing high levels of canola meal on performance of high producing Holstein cows. Anim. Feed Sci. Technol. 216:108-120.

Tamaki, N., F. Tsunemori, M. Wakabayashi, and T. Hama. 1977. Effect of histidine-free and-excess diets on anserine and carnosine contents in rat gastrocnemius. J. Nutr. Sci. Vitaminol. (Tokyo) 23:331-340.

Tomlinson, A. P., H. H. Van Horn, C. J. Wilcox, and B. Harris Jr. 1994. Effects of undegradable protein and supplemental fat on milk yield and composition and physiological responses of cows. J. Dairy Sci. 77:145-156.

Vanhatalo, A., P. Huhtanen, V. Toivonen, and T. Varvikko. 1999. Response of dairy cows fed grass silage diets to abomasal infusions of histidine alone or in combinations with methionine and lysine. J. Dairy Sci. 82:2674-2685.

Varvikko, T., A. Vanhatalo, T. Jalava, and P. Huhtanen. 1999. Lactation and metabolic responses to graded abomasal doses of methionine and lysine in cows fed grass silage diets. J. Dairy Sci. 82:2659-2673.

Vicini, J. L., J. H. Clark, W. L. Hurley, and J. M. Bahr. 1988. Effects of abomasal or intravenous administration of arginine on milk production, milk composition, and concentrations of somatotropin and insulin in plasma of dairy cows. J. Dairy Sci. 71:658-665.

Waltz, D. M., M. D. Stern, and D. J. Illg. 1989. Effect of ruminal protein degradation of blood meal and feather meal on the intestinal amino acid supply. J. Dairy Sci. 72:1509-1518.

Yeo, J.-M., C. H. Knight, and D. G. Chamberlain. 2003. Effects of changes in dietary amino acid balance on milk yield and mammary function in dairy cows. J. Dairy Sci. 86:1436-1444. 